\title{
3D distribúcia minerálnych inklúzií v granátoch z lokalít Lesné - Potičky a Beňatinská voda (Slovenská republika)
}

\author{
3D distribution of mineral inclusions in garnets from the localities Lesné - Potičky \\ and Beňatinská voda (Slovak Republic)
}

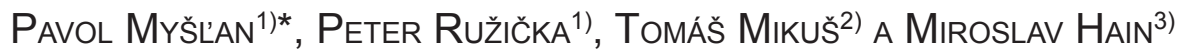 \\ 1)Katedra mineralógie a petrológie, Prírodovedecká fakulta, Univerzita Komenského v Bratislave, Ilkovičova 6, \\ Mlynská dolina, 84215 Bratislava, Slovenská republika; *e-mail: myslan.pavol@gmail.com \\ 2)Ústav vied o Zemi, Slovenská akadémia vied, Dumbierska 1, 97411 Banská Bystrica, Slovenská republika \\ 3) Ústav merania, Slovenská akadémia vied, Dúbravská cesta 9, 84104 Bratislava, Slovenská republika
}

MYšL'An P, RužıčKA P, MıKuš T, HaIN M (2020) 3D distribúcia minerálnych inklúzií v granátoch z lokalít Lesné - Potičky a Beňatinská voda (Slovenská republika). Bull Mineral Petrolog 28(2): 246-260 ISSN 2570-7337

\begin{abstract}
Visualization of garnets and their mineral inclusions was performed by X-ray microtomography by reconstructing 3D image from 1800 measured 2D X-ray projections. Visualization procedure of 3D distribution of mineral inclusions was based on the different absorption of X-ray radiation between the host garnet and mineral inclusions. 3D visualization provided a realistic picture of a distribution of the 126 identified mineral inclusions in garnet from rhyolite and rhyodacite Beňatinská voda and 21 inclusions in garnet from Lesné - Potičky (Slovak Republic). Composition of garnet from locality Lesné - Potičky is $\mathrm{Alm}_{71.0-73.7} \operatorname{Prp}_{8.3-9.0} \mathrm{Grs}_{14.7-16.6}$ and from locality Beňatinská voda is $\mathrm{Alm}_{72.1-73.2} \operatorname{Prp}_{5.5-5.9} \mathrm{Grs}_{18.3-19.4}$. Mineral inclusions in garnets from locality Lesné - Potičky are represented by fluorapatite, zircon, ilmenite, annite and magmatic melts preserved in the form of glass inclusions trapped in apatite inclusions. Mineral inclusions in garnets from locality Beňatinská voda are represented by fluorapatite, zircon and plagioclase $\mathrm{An}_{78.53-57.12}$. Chemical composition of zircons and fluorapatites are similar from both localities. Based on the chemical composition, the high-pressure origin of garnets associated with I-type magmas was confirmed.
\end{abstract}

Key words: X-ray microtomography, 3D distribution, mineral inclusions, garnet, Lesné - Potičky, Beňatinská voda, Slovak Republic

Obdrženo 18. 5. 2020; prijjato 14. 10. 2020

\section{Úvod}

Rtg. mikrotomografia je nedeštruktívna metóda priestorového zobrazovania minerálov vrátane minerálnych inklúzií. Zároveň poskytuje štatistické výstupy zamerané na kvantitatívne charakteristiky objemovej distribúcie jednotlivých fáz. Článok je zameraný na 3D rekonštrukciu objemovej distribúcie minerálnych inklúzií $v$ granátoch z lokalít Lesné - Potičky a Beňatinská voda. Na vyjadrenie chemického zloženia vizualizovaných inklúzií a hostitel'ských granátov sa použila elektrónová mikroanalýza. V texte pre označenie počítačovej tomografie sa používa jej skrátená forma $\mu \mathrm{CT}$.

\section{Lokalizácia}

Podla geomorfologického členenia lokalita Lesné - Potičky patrí do Pozdišovského chrbta Východoslovenskej pahorkatiny (Mazúr, Lukniš 1980). Tvorí súčast' Východoslovenskej nížiny, ktorá vyplńa priestor medzi Slanskými a Vihorlatskými vrchmi (obr. 1a).

Skúmaná lokalita predstavuje opustený kameňolom (obr. 1b) južne od obce Lesné sz. od Michaloviec. Poloha lokality zodpovedá $48^{\circ} 47.482^{\prime}$ severnej šírky a $21^{\circ} 48.309^{\prime}$ východnej dížky s nadmorskou výškou $220 \mathrm{~m}$.
Lokalita Beňatinská voda podla geomorfologického členenia patrí do podcelku Popriečny $v$ rámci Vihorlatských vrchov (Mazúr, Lukniš 1980). Podcelok Popriečny, vystupujúci južne od údolia potoka Beňatinská voda, tvorí súčast' morfologicky izolovaného stratovulkánu Popriečny, ktorého východná čast' sa nachádza za štátnou hranicou na území Ukrajiny (Žec et al. 1997b). Skúmaná lokalita predstavuje opustený kameňolom (obr. 1c) jv. od obce Beňatina. Poloha lokality zodpovedá $48^{\circ} 48.129^{\prime}$ severnej šírky a $22^{\circ} 21.062^{\prime}$ východnej dížky s nadmorskou výškou 527 m.

\section{Geologická charakteristika}

Telesá granátických ryolitov až ryolitových tufov pri obci Lesné (obr. 2a) vystupujú na zlomovom systémesmeru SZ-JV na sv. okraji podvihorlatskej panvy s K-Ar datovaným vekovým intervalom 14.0 - 15.2 mil. rokov (Vass et al. 1978). Na lokalite Potičky (kóta 217) sú starou lomovou t'ažbou povrchovo odkryté strmo uklonené izolované dómatické extruzívne telesá ryolitov v neogénnych sedimentoch (Baňacký et al. 1987). Ryolity majú charakteristickú fluidálnu textúru a nepravidelnú blokovú až hrubú lavicovú odlučnost'. Na protilahlej strane $1 \mathrm{~km}$ jv. od obce Lesné pod kótou Hôrka (228) sa v opustenom 
kameňolome vyskytujú prevažne ryolitové tufy (obr. 2a). Svetlosivé a doskovité ryolity z Lesného majú porfyrickú štruktúru s výrastlicami kremeňa, živcov a biotitu. Medzi výrastlicami je prítomný makroskopicky viditel'ný granát tmavočervenej farby s výrazným leskom s priemernou vel'kost'ou do $1 \mathrm{~mm}$. Základná hmota ryolitov je jemnozrnná, zložená z plagioklasov, kremeňa a sanidínu. Z akce- sorických minerálov je zastúpený zirkón a apatit, ktoré sú často uzavreté v biotite.

Ryodacitové extruzívne teleso Beňatinská voda, ktoré je súčast'ou andezitového stratovulkánu Popriečny, sa formovalo v období stredného sarmatu, čo potvrdilo $\mathrm{K}-\mathrm{Ar}$ datovanie s hodnotou $12.0 \pm 0.5$ mil. rokov (Pécskay et al. 1995; 2002). Výsledky datovania sa zhodujú s ostatný-

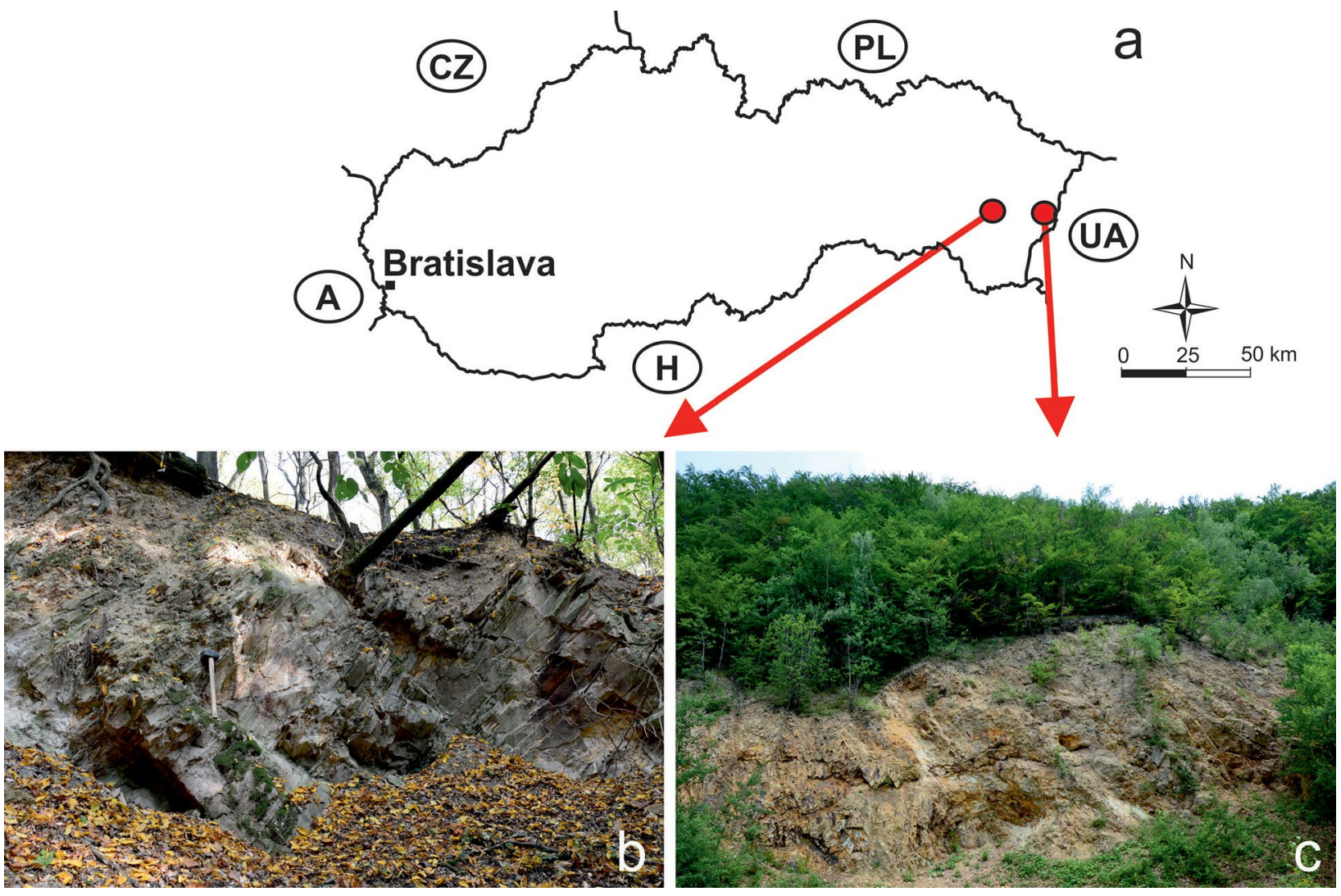

Obr. 1 Lokalizácia skúmaného územia: a) v mape Slovenskej republiky; b) pohlad na opustený kameňolom Potičky pri obci Lesné; c) opustený kameňolom v údolí potoka Beňatinská voda, šírka záberu 30 m. Foto P. Ružička 2019.
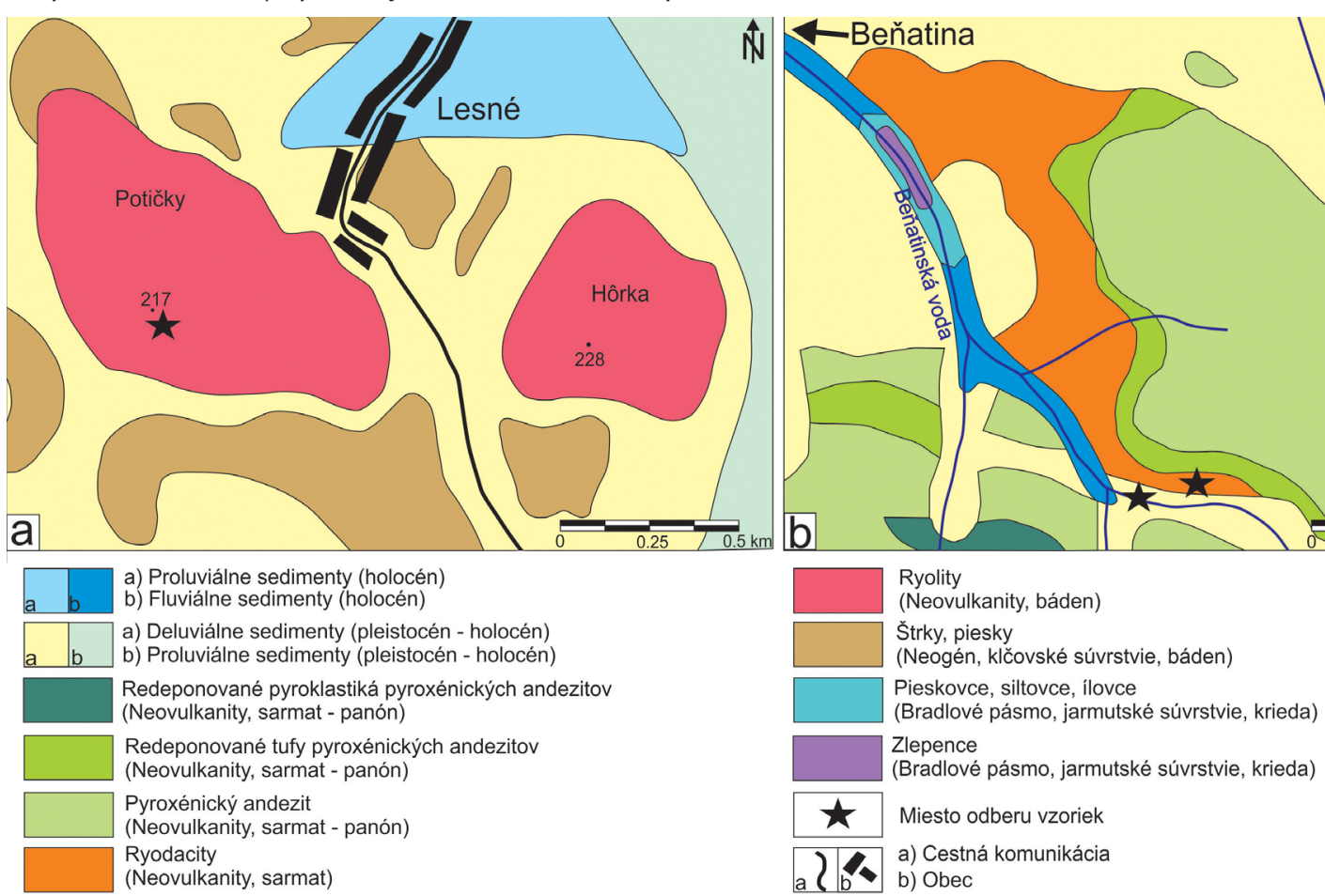

Obr. 2 Zjednodušená geologická mapa skúmaného územia: a) Lesné (mapa modifikovaná podla Baňackého (1988); b) Beňatinská voda (mapa modifikovaná podla Žeca et al. 1997a) s vyznačenými miestami odberu vzoriek. 
mi ryodacitovými extrúziami stratovulkánu Popriečny na Ukrajine (Pécskay et al. 2000). Na povrchu vystupujúce teleso granátického ryodacitu Beňatinskej vody predížené v smere SZ-JV (obr. 1c, 2b), sa nachádza v stykovej zóne bradlového pásma a vnútrokarpatského paleogénu. Vo východnej časti je ryodacitové teleso čiastočne prekryté explozívno-efuzívnymi produktmi sarmatských formácií stratovulkánu Popriečny. Vnútorná stavba telesa je dobre odkrytá v opustenom kameňolome na jeho južnej strane. Svetlý ryodacit má hrubostĺpcovú odlučnost' s náznakom vejárovitej stavby. V okrajovej časti telesa je tmavý ryodacit s fluidálnou textúrou. Hornina je slabo porfyrická, výrastlice živcov dosahujú vel'kost' $1.5 \mathrm{~mm}$ a výrastlice kremeňa priemerne do $1 \mathrm{~mm}$. Štruktúra základnej hmoty je mikroliticko-felzitická, tvorená lištami biotitu a živcov (vel'kost' $0.2-0.8 \mathrm{~mm}$ ), drobnejšími mikrolitmi a rekryštalizovaným sklom. Na okraji telesa je vyvinutá brekcia tvorená úlomkami sklovitého ryodacitu a úlomkami paleogénnych sedimentov (Kaličiak et al. 1995; Žec et al. 1997b).

\section{Metodika}

Vzorky granátických ryolitov (Lesné - Potičky) až ryodacitov (Beňatina) boli odoberané z opustených kameňolomov a z hornej časti potoka Beňatinská voda (obr. 2). Štúdium priestorovej distribúcie a objemovej kvantifikácie minerálnych inklúzií $v$ granátoch prebiehalo pomocou metódy rtg. mikrotomografie. Na Ústave merania SAV v Bratislave bol priestorovo skenovaný jeden granát $z$ lokality Lesné - Potičky a jeden z lokality Beňatinská voda na rtg. mikrotomografe Nanotom 180 (GE Phoenix). Mikrotomografické snímanie $(\mu \mathrm{CT})$ granátov bolo realizované pri nasledovných analytických podmienkach: urýchl'ovacie napätie $150 \mathrm{kV}$, prúd $90 \mathrm{~mA}$, akumulačný čas detektora 500 ms. Transmisný volfrámový terčík predstavuje bodový zdroj rtg. žiarenia s nanofokusáciou a výkonom $15 \mathrm{~W}$. Detektor rtg. žiarenia scintilačného typu (CsI) s maticovým fotodetektorom má rozlíšenie 2300 x 2300 pixelov (jeden pixel má $50 \times 50 \mu \mathrm{m}$ ). Voxelové rozlíšenie pri re-
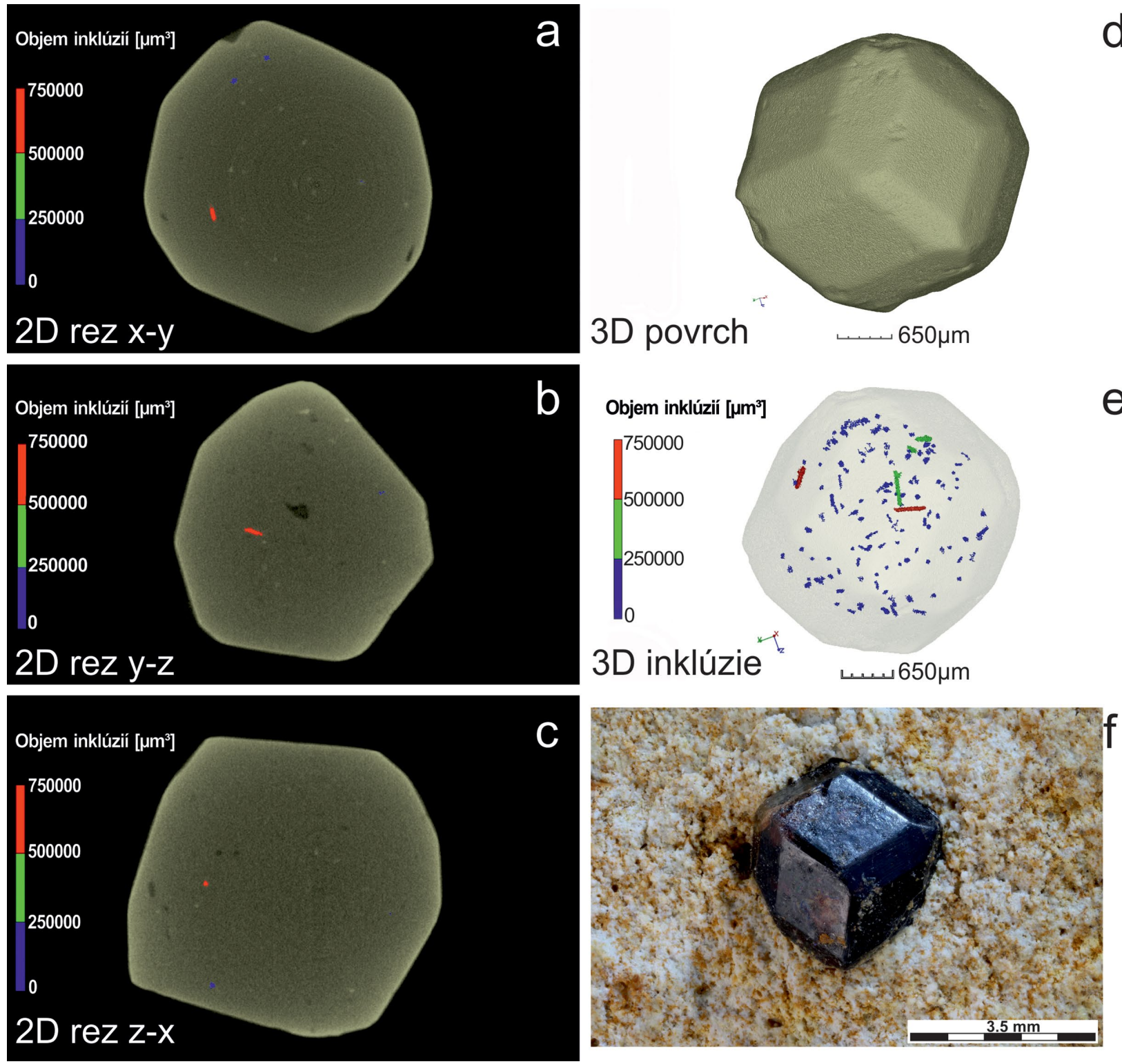

Obr. 3 Výsledky mikrotomografického snímania granátu z lokality Beňatinská voda (vzorka Ben-1): a-c) 2D rezy $v$ troch kolmých rovinách; d) 3D vizualizácia povrchu granátu; e) 3D vizualizácia distribúcie 126 minerálnych inklúzií $v$ granáte s pseudofarebne zvýraznenými detailmi skupinových objemových vel'kostí v transparentne upravenom hostitel'skom granáte. Foto M. Hain; f) pozícia granátu v ryodacite. Foto J. Demian. 


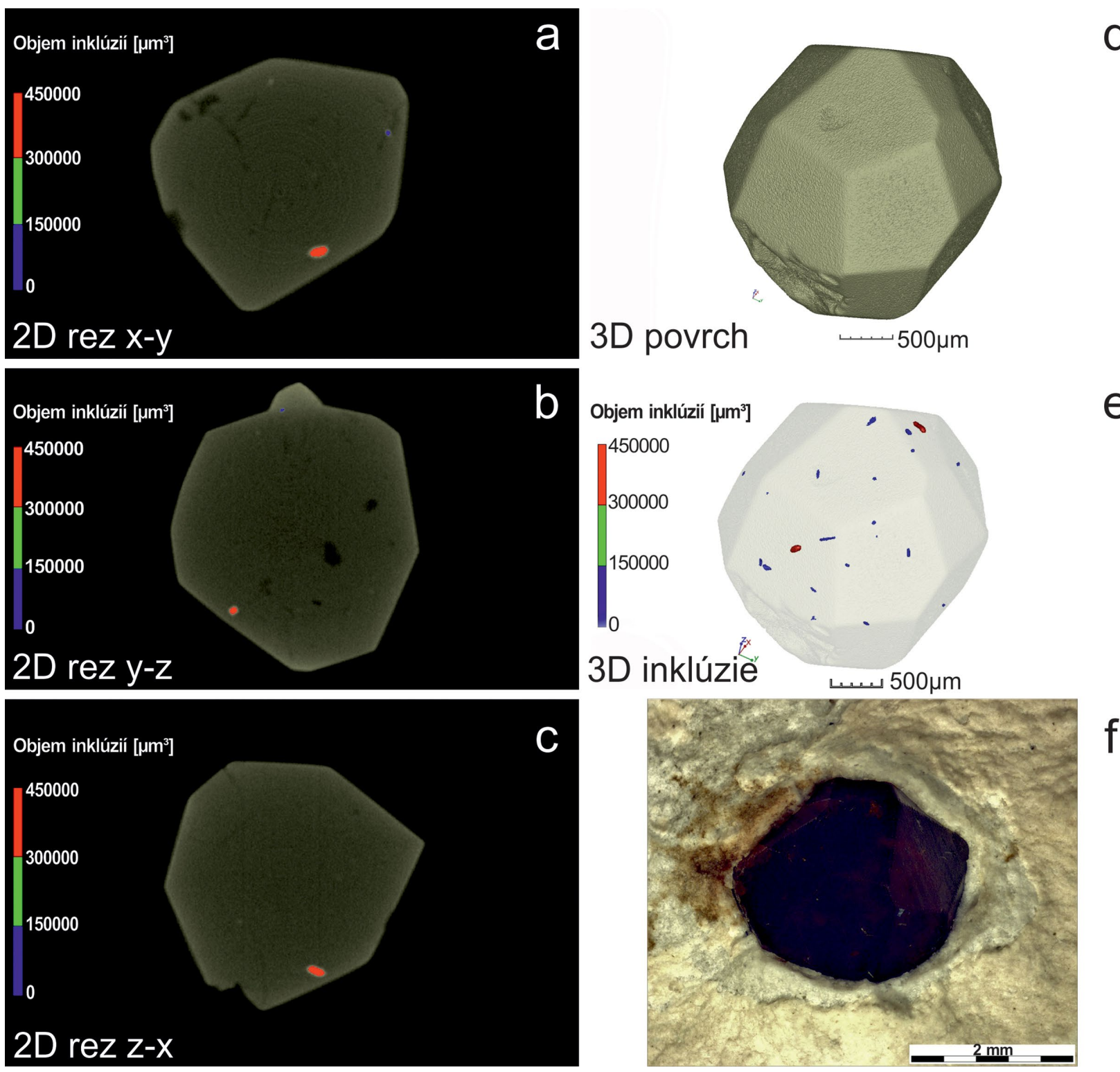

Obr. 4 Výsledky mikrotomografického snímania granátu z lokality Lesné - Potičky (vzorka Les-2): a-c) 2D rezy $v$ troch kolmých rovinách; d) 3D vizualizácia povrchu granátu; e) 3D vizualizácia distribúcie 21 minerálnych inklúzií $v$ granáte s pseudofarebne zvýraznenými detailmi skupinových objemových vel'kostí v transparentne upravenom hostitel'skom granáte. Foto M. Hain; f) pozícia granátu v ryolite. Foto P. Myšlan.

Obr. 5 Distribučný graf vyjadrujúci početnost' objemového zastúpenia minerálnych inklúzii $v$ dvoch rtg. mikrotomograficky analyzovaných granátoch z lokalít Lesné a Beňatina.

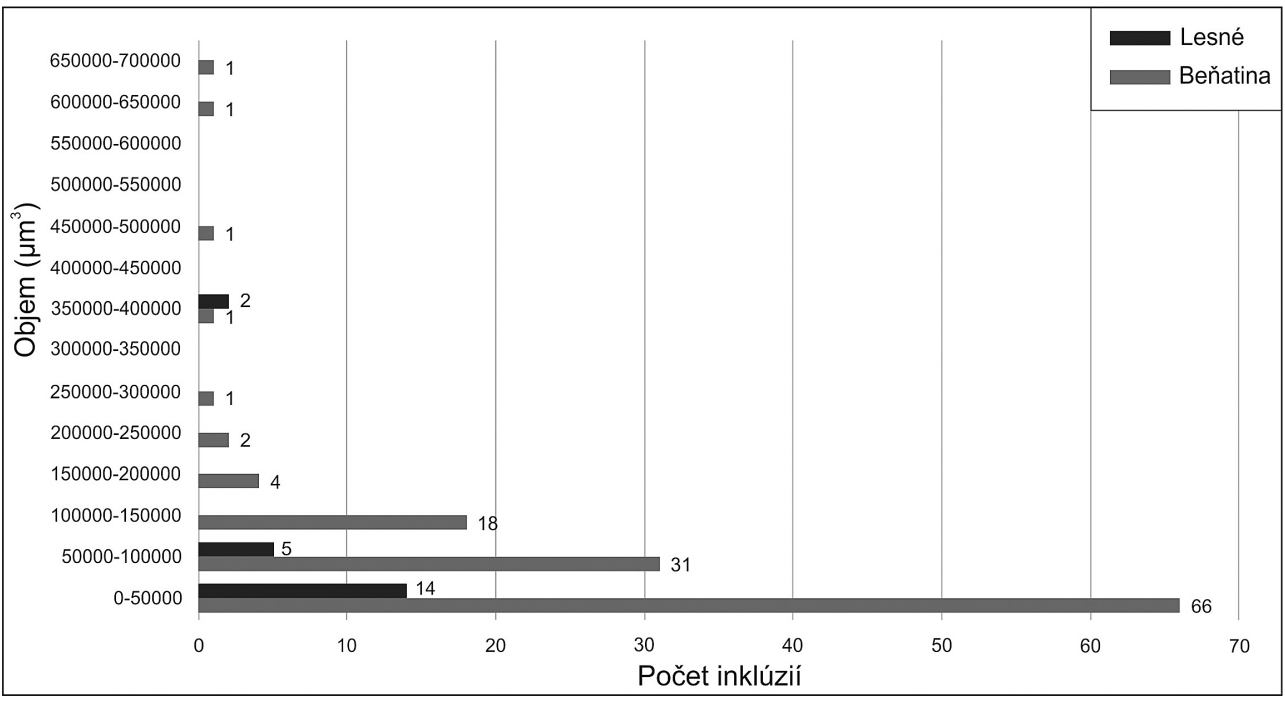



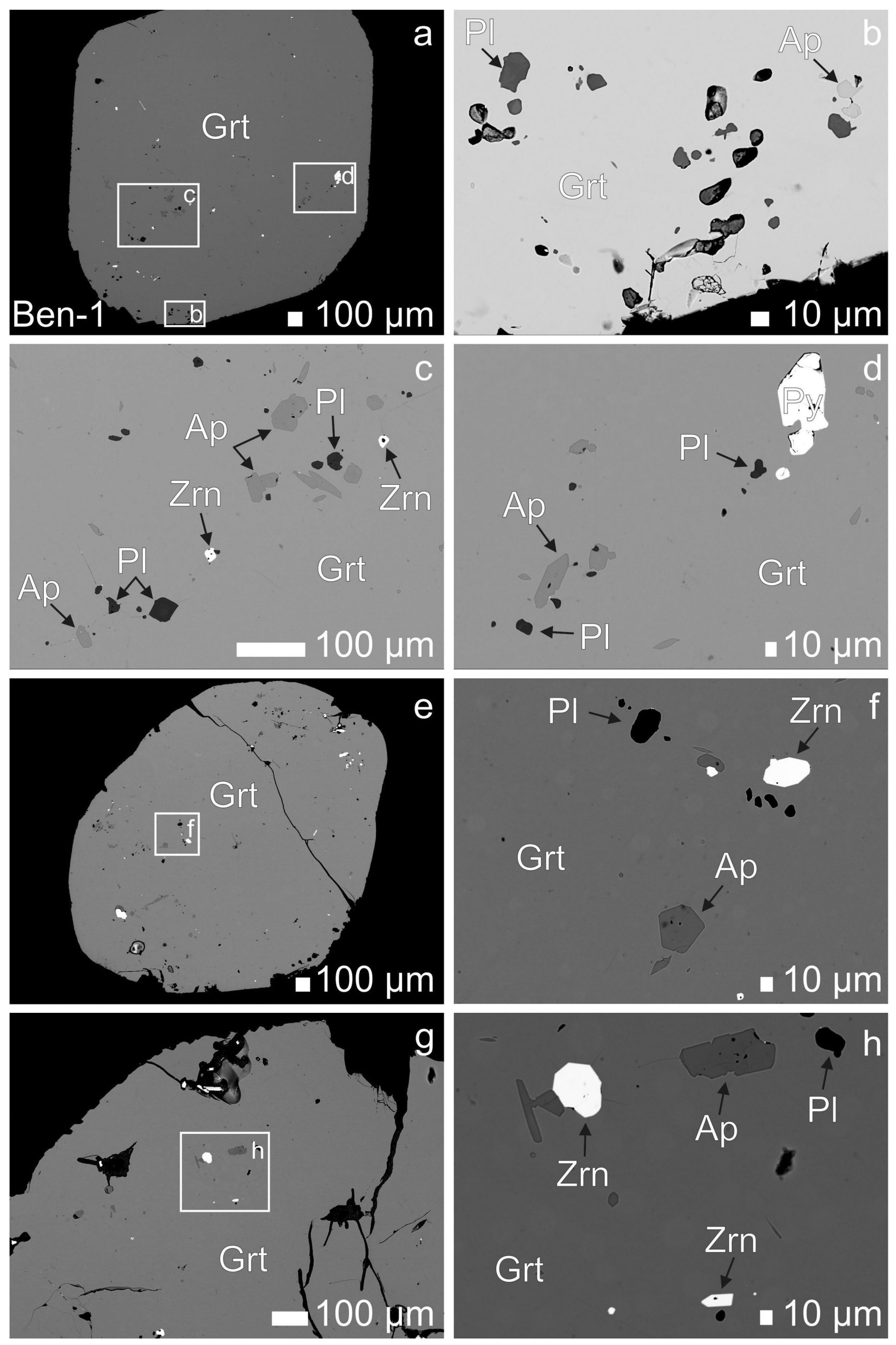
Obr. 6 BSE zobrazenie analyzovaných fáz prítomných v granátoch z lokality Beňatinská voda. Foto T. Mikuš. Skratky minerálov: Grt - granát, Zrn - zirkón, Ap - apatit, PI - plagioklas, Py - pyrit. Vzorka Ben-1 je granát, ktorý bol mikrotomograficky spracovaný.

$\leftarrow$

konštrukcii 3D obrazu dosahuje minimálnu hodnotu 0.5 um pri objektoch vel'kých $1 \mathrm{~mm}$.

Postup snímania, spracovania a vyhodnotenia $\mu \mathrm{CT}$ granátov prebiehal $v$ troch fázach:

1. Fáza snímania 1800 röntgenových 2D projekcií granátu v kužel'ovom rtg. zväzku premietaných na plošný 2D detektor postupnou rotáciou granátu okolo svojej osi o $360^{\circ} \mathrm{s}$ definovaným krokom uhlového pootočenia o $0^{\circ} 12^{\prime}$;

2. Fáza počítačovej rekonštrukcie 3D obrazu zo súboru nameraných 2D rtg. projekcií pomocou klastra ôsmych vysokovýkonných počítačov s využitím rekonštrukčného softvéru Datos|x;

3. Fáza počítačového spracovania, 3D vizualizácie a analýzy objemových dát pomocou softvéru VG StudioMAX $2.1 \mathrm{~s}$ ciel'om objemovej kvantifikácie a stanovenia distribúcie minerálnych inklúzií v granáte.

$\mathrm{Na}$ získanie štatistických údajov bolo vyseparovaných 16 granátov z obidvoch lokalít, ktoré boli následne použité na identifikáciu chemického zloženia granátov a ich minerálnych inklúzií. Zhotovené leštené nábrusy po naparení uhlíkom boli študované v elektrónovom mikroanalyzátore JEOL JXA 8530FE na Ústave vied o Zemi
Slovenskej akadémie vied v Banskej Bystrici. Vzorky boli analyzované pri urýchl'ovacom napätí $15 \mathrm{kV}$ a prúde 20 nA. Priemer elektrónového lúča sa prispôsoboval počas merania v rozsahu $1-8 \mu \mathrm{m}$. Použila sa ZAF korekcia. Plošná distribúcia minerálnych inklúzií $v$ granátoch sa pozorovala v spätne rozptýlených elektrónoch (BSE - back scattered electron). Na meranie silikátov, apatitu a Fe-Ti oxidov boli použité prírodné a syntetické štandardy (rtg. línie): Si (Ka) - ortoklas a albit, $\mathrm{Ti}(\mathrm{K \alpha})$ - rutil, $\mathrm{Zr}(\mathrm{L \alpha})$ - kubická zirkónia, $\mathrm{Al}(\mathrm{K \alpha})$ - albit a ortoklas, $\mathrm{Fe}(\mathrm{Ka})$ - hematit, $\mathrm{Zn}(\mathrm{K \alpha})$ - gahnit, $\mathrm{Sr}(\mathrm{L \alpha})$ - celestín, Mn (Ka) - rodonit, Mg $(K \alpha)$ - diopsid a biotit, $\mathrm{Ca}(\mathrm{K \alpha})$ - diopsid a apatit, $\mathrm{Na}(\mathrm{Ka})$ - albit, K (Ka) - ortoklas, Ba (La) - barit, P (Ka) - apatit, F $(K \alpha)$ - fluorit, $\mathrm{Cl}(\mathrm{K} \alpha)$ - tugtupit, $\mathrm{S}(\mathrm{K} \alpha)$ - barit, $\mathrm{Hf}(\mathrm{M \alpha})$ kubická zirkónia, Th (Ma) - torianit, $\mathrm{U}(\mathrm{M} \beta)-\mathrm{UO}_{2}, \mathrm{Sc}(\mathrm{K \alpha})$ - $\mathrm{ScVO}_{4}, \mathrm{Y}(\mathrm{L \alpha})-\mathrm{YPO}_{4}$, La (La) - $\mathrm{LaPO}_{4}, \mathrm{Ce}(\mathrm{L \alpha})-\mathrm{CePO}_{4}$, Dy $(L \alpha)-\mathrm{DyPO}_{4}, \mathrm{Er}(\mathrm{L \alpha})-\mathrm{ErPO}_{4}, \mathrm{Yb}(\mathrm{L \alpha})-\mathrm{YbPO}_{4}, \mathrm{Lu}$ $(\mathrm{L \alpha})-\mathrm{LuPO}_{4}, \mathrm{Nb}(\mathrm{L \alpha})-\mathrm{LiNbO}_{3}, \mathrm{Sm}(\mathrm{L} \beta)-\mathrm{SmPO}_{4}, \mathrm{Pr}$ $(\mathrm{L} \beta)-\mathrm{PrPO}_{4}, \mathrm{Nd}(\mathrm{L} \alpha)-\mathrm{NdPO}_{4}$. Elektrónové mikroanalýzy boli prepočítané $v$ zmysle platných klasifikácií granátov (Grew et al. 2013), slúd (Tischendorf et al. 2007) a apatitu (Pasero et al. 2010). V texte používané slovenské názvy minerálov sú upravené podl'a Ozdína a Uhera (2002).

Tabul'ka 1 Reprezentatívne elektrónové mikroanalýzy granátov ( $\mathrm{hm}$. \%) prepočítané na 8 katiónov (apfu) a zastúpenie ich koncových členov (mol. \%). Obsahy $\mathrm{FeO}$ a $\mathrm{Fe}_{2} \mathrm{O}_{3}$ boli prepočítané na základe nábojovej bilancie molekuly.

\begin{tabular}{|c|c|c|c|c|c|c|c|c|c|c|c|c|}
\hline Lokalita & \multicolumn{6}{|c|}{ Beňatinská voda } & \multicolumn{6}{|c|}{ Lesné - Potičky } \\
\hline Analýza & 1 & 2 & 3 & 4 & 5 & 6 & 1 & 2 & 3 & 4 & 5 & U \\
\hline $\mathrm{SiO}_{2}$ & 36.35 & 36.95 & 36.19 & 36.44 & 36.48 & 36.43 & 37.32 & 37.29 & 37.39 & 37.31 & 37.64 & 37.44 \\
\hline $\mathrm{TiO}_{2}$ & 0.37 & 0.38 & 0.38 & 0.44 & 0.37 & 0.34 & 0.29 & 0.22 & 0.26 & 0.27 & 0.27 & 0.27 \\
\hline $\mathrm{Al}_{2} \mathrm{O}_{3}$ & 20.21 & 20.70 & 20.31 & 20.38 & 20.21 & 20.47 & 21.05 & 21.11 & 21.12 & 20.88 & 21.24 & 21.03 \\
\hline $\mathrm{Fe}_{2} \mathrm{O}_{3}$ & 1.42 & 1.26 & 0.99 & 1.42 & 1.25 & 0.67 & 0.13 & 0 & 0 & 0 & 0 & 0 \\
\hline $\mathrm{FeO}$ & 32.04 & 32.24 & 31.60 & 31.72 & 31.78 & 31.96 & 32.23 & 32.26 & 32.05 & 31.89 & 32.00 & 31.90 \\
\hline $\mathrm{MnO}$ & 95 & 0.98 & 0.84 & 1.07 & 0.97 & 0.84 & 1.58 & 1.52 & 1.60 & 1.26 & .68 & 1.71 \\
\hline $\mathrm{MgO}$ & 1.35 & 1.39 & 1.37 & 1.31 & 1.45 & 1.38 & 2.27 & 2.22 & 2.17 & 2.19 & 2.15 & 2.17 \\
\hline $\mathrm{CaO}$ & 6.54 & 6.89 & 6.81 & 6.90 & 6.72 & 6.70 & 5.48 & 5.24 & 5.64 & 5.60 & 5.52 & 5.83 \\
\hline Suma & 9.24 & 00.77 & 98.50 & 99.67 & 99.23 & 98.80 & 100.33 & 99.85 & 100.23 & 99.39 & 100.50 & 100.35 \\
\hline $\mathrm{Si}^{4+}$ & 963 & 962 & 2.965 & 2.956 & 2.969 & 2.974 & 2.986 & 2.998 & 2.994 & 3.011 & 3.006 & 2.995 \\
\hline $\mathrm{Al}^{3+}$ & 037 & 0.038 & 0.035 & 0.044 & 0.031 & 0.026 & 14 & 0.002 & 0.006 & 0 & 0 & 0.005 \\
\hline Sume & 3.000 & 3.000 & 3.000 & 3.000 & 3.000 & 3.000 & 3.000 & 3.000 & 3.000 & 3.011 & 3.006 & 3.000 \\
\hline $\mathrm{Ti}^{4+}$ & 0.022 & 0.023 & 0.023 & 0.027 & 0.023 & 0.021 & 0.017 & 0.013 & 0.016 & 0.016 & 0.016 & 0.016 \\
\hline $\mathrm{Al}^{3+}$ & 1.905 & 1.917 & 1.927 & 1.904 & 1.909 & 1.943 & 1.971 & 1.997 & 1.987 & 1.987 & 1.999 & 1.976 \\
\hline $\mathrm{Fe}^{3+}$ & 0.087 & 0.076 & 0.061 & 0.087 & 0.077 & 0.041 & 0.008 & 0 & 0 & 0 & 0 & 0 \\
\hline Suma & 2.015 & 2.016 & 2.011 & 2.017 & 2.008 & 2.005 & 96 & 2.011 & 2.002 & 2.003 & 2.016 & 1.992 \\
\hline $\mathrm{Fe}^{2+}$ & 2.184 & 61 & 2.165 & 2.152 & 2.163 & 2.182 & 2.157 & 2.169 & 2.146 & 2.152 & 2.137 & 2.134 \\
\hline $\mathrm{Mn}^{2+}$ & 0.066 & 0.067 & 0.058 & 0.074 & 0.067 & 0.058 & 0.107 & 0.103 & 0.109 & 0.086 & 0.114 & 0.116 \\
\hline $\mathrm{Mg}^{2+}$ & 0.164 & 0.165 & 0.167 & 0.158 & 0.175 & 0.168 & 0.270 & 0.266 & 0.259 & 0.264 & 0.256 & 0.259 \\
\hline $\mathrm{Ca}^{2+}$ & 0.571 & 0.591 & 0.598 & 0.599 & 0.586 & 0.586 & 0.470 & 0.451 & 0.484 & 0.484 & 0.472 & 0.499 \\
\hline Suma $X$ & 2.985 & 2.984 & 2.989 & 2.983 & 2.992 & 2.995 & 3.004 & 2.989 & 2.998 & 2.986 & 2.979 & 3.008 \\
\hline Alm & 73.16 & 72.41 & 72.44 & 72.14 & 72.30 & 72.86 & 71.81 & 72.77 & 71.71 & 72.46 & 72.14 & 70.97 \\
\hline Prp & 5.51 & 5.55 & 5.60 & 5.29 & 5.86 & 5.62 & 9.00 & 8.82 & 8.61 & 8.71 & 8.46 & 8.60 \\
\hline Sps & 2.21 & 2.23 & 1.96 & 2.47 & 2.23 & 1.94 & 3.55 & 3.43 & 3.61 & 2.83 & 3.76 & 3.85 \\
\hline Adr & 0.82 & 0.74 & 0.60 & 0.86 & 0.75 & 0.40 & 0.06 & 0 & 0 & 0 & 0 & 0 \\
\hline Grs & 18.31 & 19.07 & 19.39 & 19.24 & 18.85 & 19.17 & 15.58 & 15.09 & 16.13 & 16.22 & 15.86 & 16.60 \\
\hline
\end{tabular}



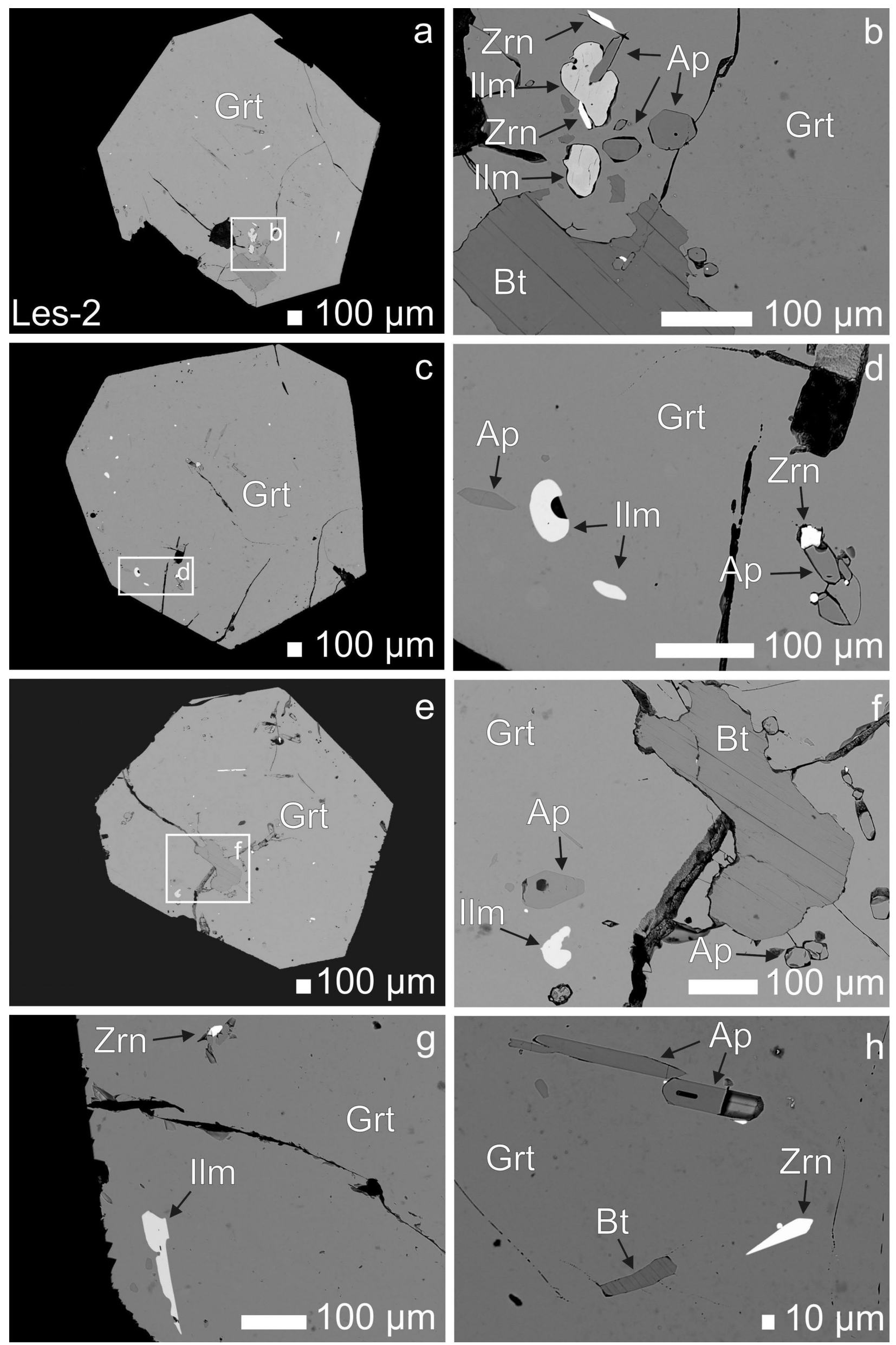

Grt

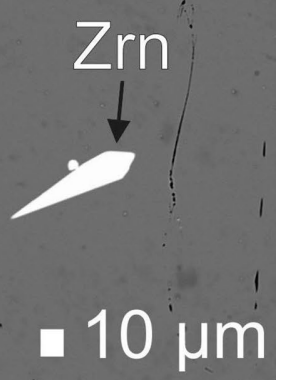


Obr. 7 BSE zobrazenie analyzovaných fáz prítomných v granátoch z lokality Lesné - Potičky. Foto T. Mikuš. Skratky minerálov: Grt - granát, Zrn - zirkón, Ap - apatit, Bt - biotit (annit), Ilm - ilmenit. Vzorka Les-2 je granát, ktorý bol mikrotomograficky spracovaný.

\section{Výsledky}

\section{D distribúcia minerálnych inklúzií v granátoch}

$\mathrm{K}$ prvým $\mu \mathrm{CT}$ výstupom patria $2 \mathrm{D}$ projekcie granátov z Lesného (obr. 3a-c) a Beňatinskej vody (obr. 4a-c) v rôzne zvolených rovinách resp. rezoch. Následne z nich boli rekonštruované $3 \mathrm{D}$ vizualizácie povrchu granátov $\mathrm{s}$ viditel'nými kryštálovými plochami a s finálnym zobrazením vnútornej konfigurácie minerálnych inklúzií (obr. 3d-e, $4 d-e)$. Makroskopicky sú dobre rozpoznatel'né kryštálové tvary granátov (obr. 3f, 4f). Granát z lokality Lesné - Potičky má prevládajúci kryštálový tvar tetragón-tri-oktaéder a granát z lokality Beňatinská voda má tvary rombododekaédra a tetragón-tri-oktaédra.

Postup vizualizácie 3D distribúcie minerálnych inklúzií vychádzal z rozdielnej absorpcie meracieho zväzku rtg. žiarenia medzi hostitel'ským granátom a jeho inklúziami. Inklúzie prejavovali najvyššiu absorpciu, pretože oproti granátom majú odlišné chemické zloženie, čím vytvárajú dostatočný obrazový kontrast. Na základe vyššej lokálnej absorpcie rtg. žiarenia $v$ oblasti minerálnych inklúzií bolo možné v 3D rekonštruovanom obraze vyextrahovat' jednotlivé inklúzie $s$ ich prirodzeným tvarovým ohraničením.
Výsledná 3D vizualizácia poskytla reálny distribučný obraz objemového zastúpenia minerálnych inklúzií v granátoch, ktorá bola štatisticky spracovaná. Jednotlivé vel'kostné skupiny objemového zastúpenia minerálnych inklúzií v granátoch boli pseudofarebne zvýraznené (obr. 3e, 4e).

V granáte vel'kosti $2.6 \mathrm{~mm}$ z lokality Lesné - Potičky bolo identifikovaných 21 minerálnych inklúzií s rôznym objemovým zastúpením (obr. 5). V granáte vel'kosti 3.5 $\mathrm{mm}$ z lokality Beňatinská voda bolo identifikovaných 126 minerálnych inklúzií $s$ variabilným objemovým zastúpením (obr. 5).

\section{Identifikácia granátov a minerálnych inklúzií}

Plošnú distribúciu zastúpenia minerálnych inklúzií $\checkmark$ granátoch poskytlo štúdium nábrusov $v$ režime BSE (obr. 6, 7, 8). Prevažne tmavočervené granáty z lokalít Lesné - Potičky a Beňatinská voda majú dominantne zastúpenú almandínovú zložku (70.97 - 73.16 mol. \%) s nižším podielom grosulárovej zložky (15.09 - 19.39 mol. \%) a minimálne je zastúpená pyropová (5.29 - 9.00 mol. $\%)$, spessartínová (1.96 - 3.85 mol. \%) a andraditová (0 - 0.86 mol. \%) zložka (obr. 9a; tab. 1). Granáty z lokality Lesné - Potičky majú voči granátom z lokality Beňatinská
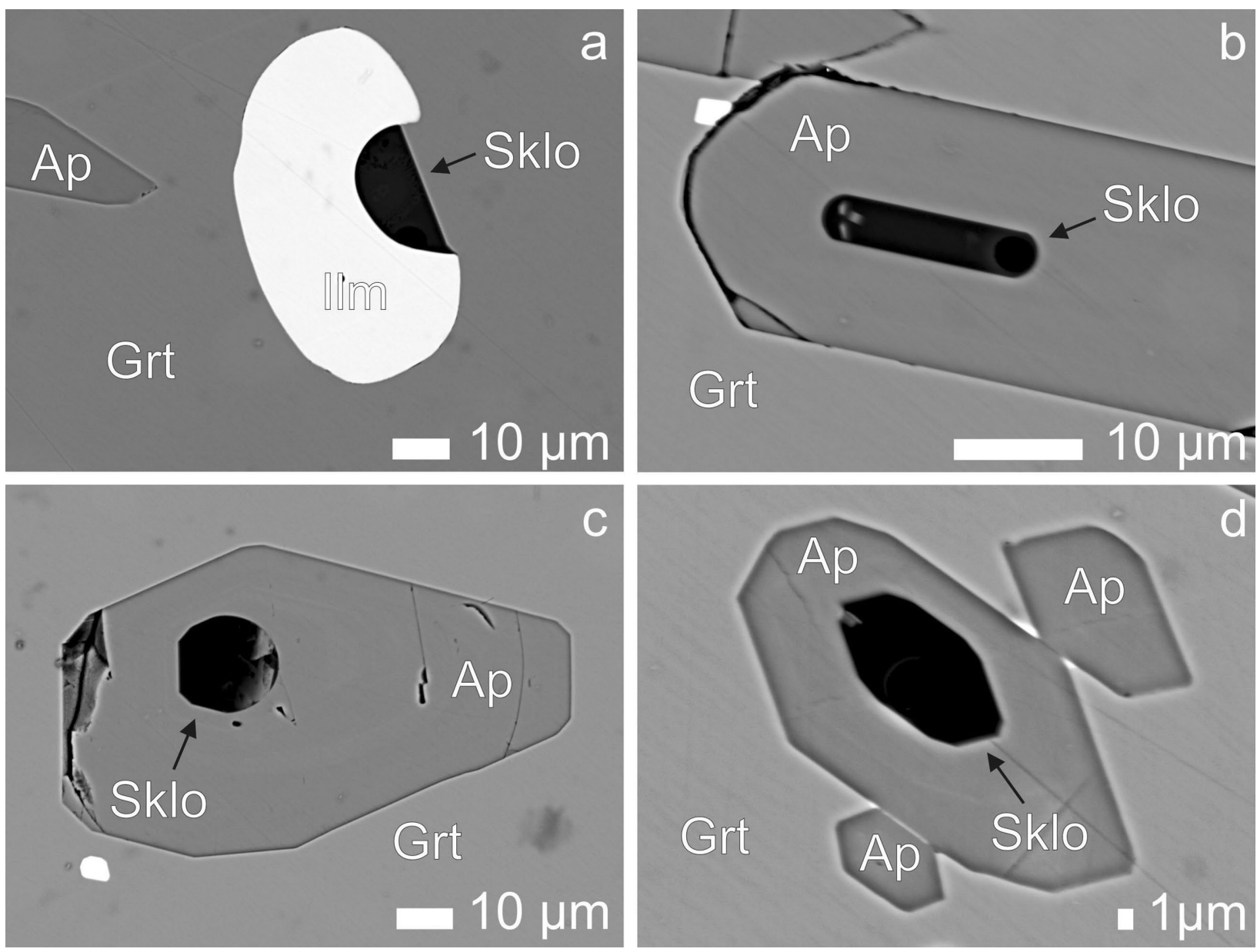

Obr. 8 BSE zobrazenie analyzovaných tavenín v granátoch z lokality Lesné - Potičky. Foto T. Mikuš. Skratky minerálov:

Grt - granát, Ap - apatit, IIm - ilmenit. 
voda viac zastúpenú pyropovú a spessartínovú zložku, menej dominantná je almandínová a grosulárová zložka. $\checkmark$ granátoch z lokality Beňatinská voda (obr. 6) boli identifikované minerálne inklúzie zastúpené zirkónom (tab. 2), fluórapatitom (tab. 3; obr. 9b), plagioklasom (tab. 5; obr. 9c), minoritne aj pyritom. Plagioklasy majú zloženie $A n_{78.53-57.12}$. Z minerálnych inklúzií bol v granátoch (obr. 7) z lokality Lesné - Potičky identifikovaný zirkón (tab. 2), fluórapatit (tab. 3; obr. 9b), ilmenit (tab. 4), annit (tab. 6; obr. 9d) a tavenina acídneho zloženia (tab. 7; obr. 11). IImenit obsahuje 1.99 - 2.26 mol. \% geikielitovej $\left(\mathrm{MgTiO}_{3}\right)$ a $1.11-1.27$ mol. \% pyrofanitovej $\left(\mathrm{MnTiO}_{3}\right)$ komponenty. Minerály apatitovej superskupiny sú dominantne zastúpené fluórapatitom na obidvoch lokalitách, s podielom $\mathrm{F}$ 0.582 - 0.726 apfu, $\mathrm{Cl} 0.034-0.042$ apfu a $\mathrm{OH} 0.236$ -
0.378 apfu. Zirkóny zo skúmaných lokalít obsahujú 0.011 - 0.016 apfu $\mathrm{Hf}$ bez výrazného obohatenia o Y+REE prvky (max. do 0.016 apfu).

\section{Genetická interpretácia granátov a inklúzií tavenín}

Primárne magmatické granáty s dominantným zastúpením almandínovej zložky na základe experimentálnych údajov (Green 1977) môžu kryštalizovat' priamo z peraluminóznej silikátovej taveniny vo vysokotlakových podmienkach (nad $7 \mathrm{kbar})$ a pri vyšších teplotách $\left(\sim 1000^{\circ} \mathrm{C}\right)$ indikujúcich híbku nad $25 \mathrm{~km}$. Od metamorfného pôvodu sa odlišujú neprítomnost'ou metamorfných fáz (staurolit, sillimanit, cordierit) a charakteristickým tvarom ich okrajov. Nízky obsah MnO (do 2 hm. \%) a vyšší obsah $\mathrm{CaO}$ (nad $5 \mathrm{hm} . \%$ ) indikuje magmatický pôvod granátov vykryštalizovaných z taveniny uloženej v magmatickom rezervoári

Tabul'ka 2 Reprezentatívne elektrónové mikroanalýzy zirkónu ( $\mathrm{hm}$. \%) prepočítané na 4 kyslíky (apfu).

\begin{tabular}{|c|c|c|c|c|c|c|c|c|c|c|}
\hline Lokalita & & Ber & tinská vo & & & & Les & é - Potičk & & \\
\hline Analýza & 1 & 2 & 3 & 4 & 5 & 1 & 2 & 3 & 4 & 5 \\
\hline $\mathrm{SiO}_{2}$ & 32.90 & 32.61 & 32.67 & 32.39 & 32.92 & 32.83 & 32.93 & 32.92 & 31.99 & 32.22 \\
\hline $\mathrm{TiO}_{2}$ & 0 & 0.09 & 0.04 & 0.05 & 0 & 0.10 & 0.37 & 0.14 & 0.06 & 0.03 \\
\hline $\mathrm{ZrO}_{2}$ & 64.74 & 65.64 & 64.23 & 65.12 & 63.56 & 61.70 & 64.51 & 65.25 & 64.29 & 65.44 \\
\hline $\mathrm{HfO}_{2}$ & 1.28 & 1.30 & 1.82 & 1.24 & 1.39 & 1.34 & 1.35 & 1.50 & 1.41 & 1.21 \\
\hline $\mathrm{ThO}_{2}$ & 0.05 & 0.03 & 0.03 & 0.09 & 0.01 & 0.20 & 0.16 & 0.10 & 0.01 & 0.14 \\
\hline $\mathrm{UO}_{2}$ & 0.06 & 0.11 & 0.07 & 0.10 & 0.07 & 0.19 & 0.22 & 0.12 & 0.08 & 0.12 \\
\hline $\mathrm{Al}_{2} \mathrm{O}_{3}$ & 0.08 & 0.01 & 0 & 0.01 & 0.74 & 0.86 & 0.02 & 0.07 & 0.16 & 0 \\
\hline $\mathrm{Sc}_{2} \mathrm{O}_{3}$ & 0 & 0 & 0 & 0 & 0 & 0.02 & 0.07 & 0.04 & 0 & 0.11 \\
\hline $\mathrm{Y}_{2} \mathrm{O}_{3}$ & 0.14 & 0.16 & 0.04 & 0.22 & 0.10 & 0.69 & 0.59 & 0.25 & 0.20 & 0.56 \\
\hline $\mathrm{La}_{2} \mathrm{O}_{3}$ & 0.01 & 0 & 0.01 & 0 & 0 & 0 & 0 & 0 & 0.01 & 0 \\
\hline $\mathrm{Ce}_{2} \mathrm{O}_{3}$ & 0.03 & 0.02 & 0 & 0 & 0 & 0.04 & 0 & 0.01 & 0.01 & 0.09 \\
\hline $\mathrm{Dy}_{2} \mathrm{O}_{3}$ & 0.10 & 0.04 & 0.08 & 0.04 & 0.01 & 0.12 & 0.09 & 0.03 & 0.05 & 0.06 \\
\hline $\mathrm{Er}_{2} \mathrm{O}_{3}$ & 0 & 0.05 & 0.02 & 0.04 & 0.02 & 0.13 & 0.13 & 0 & 0.04 & 0.12 \\
\hline $\mathrm{Yb}_{2} \mathrm{O}_{3}$ & 0.09 & 0.05 & 0.05 & 0.12 & 0.07 & 0.18 & 0.14 & 0.06 & 0.03 & 0.33 \\
\hline $\mathrm{Lu}_{2} \mathrm{O}_{3}$ & 0 & 0 & 0 & 0 & 0.02 & 0.02 & 0 & 0.01 & 0.06 & 0.04 \\
\hline $\mathrm{FeO}$ & 1.14 & 0.87 & 0.89 & 0.88 & 0.85 & 2.08 & 1.14 & 1.14 & 0.72 & 1.04 \\
\hline $\mathrm{MnO}$ & 0 & 0.06 & 0.11 & 0.09 & 0.05 & 0.19 & 0.04 & 0.01 & 0 & 0.02 \\
\hline $\mathrm{CaO}$ & 0.05 & 0.03 & 0.03 & 0.03 & 0.45 & 0.34 & 0.05 & 0.08 & 0.31 & 0.04 \\
\hline $\mathrm{BaO}$ & 0.20 & 0.13 & 0 & 0 & 0 & 0.04 & 0.03 & 0.21 & 0 & 0 \\
\hline Suma & 100.85 & 101.20 & 100.08 & 100.40 & 100.25 & 101.05 & 101.83 & 101.93 & 99.43 & 101.56 \\
\hline $\mathrm{Si}$ & 1.003 & 0.994 & 1.004 & 0.995 & 1.003 & 0.998 & 0.997 & 0.996 & 0.991 & 0.984 \\
\hline $\mathrm{Ti}$ & 0 & 0.002 & 0.001 & 0.001 & 0 & 0.002 & 0.008 & 0.003 & 0.001 & 0.001 \\
\hline $\mathrm{Al}$ & 0.003 & 0 & 0 & 0 & 0.027 & 0.031 & 0.001 & 0.002 & 0.006 & 0 \\
\hline Suma $B$ & 1.006 & 0.996 & 1.005 & 0.996 & 1.029 & 1.031 & 1.006 & 1.002 & 0.998 & 0.985 \\
\hline $\mathrm{Zr}$ & 0.963 & 0.975 & 0.963 & 0.975 & 0.944 & 0.915 & 0.953 & 0.963 & 0.971 & 0.975 \\
\hline $\mathrm{Hf}$ & 0.011 & 0.011 & 0.016 & 0.011 & 0.012 & 0.012 & 0.012 & 0.013 & 0.012 & 0.011 \\
\hline Th & 0 & 0 & 0 & 0.001 & 0 & 0.001 & 0.001 & 0.001 & 0 & 0.001 \\
\hline U & 0 & 0.001 & 0 & 0.001 & 0 & 0.001 & 0.001 & 0.001 & 0.001 & 0.001 \\
\hline Sc & 0 & 0 & 0 & 0 & 0 & 0.001 & 0.002 & 0.001 & 0 & 0.003 \\
\hline Y & 0.002 & 0.003 & 0.001 & 0.004 & 0.002 & 0.011 & 0.010 & 0.004 & 0.003 & 0.009 \\
\hline La & 0 & 0 & 0 & 0 & 0 & 0 & 0 & 0 & 0 & 0 \\
\hline $\mathrm{Ce}$ & 0 & 0 & 0 & 0 & 0 & 0 & 0 & 0 & 0 & 0.001 \\
\hline Dy & 0.001 & 0 & 0.001 & 0 & 0 & 0.001 & 0.001 & 0 & 0.001 & 0.001 \\
\hline $\mathrm{Er}$ & 0 & 0 & 0 & 0 & 0 & 0.001 & 0.001 & 0 & 0 & 0.001 \\
\hline $\mathrm{Yb}$ & 0.001 & 0 & 0 & 0.001 & 0.001 & 0.002 & 0.001 & 0.001 & 0 & 0.003 \\
\hline Lu & 0 & 0 & 0 & 0 & 0 & 0 & 0 & 0 & 0.001 & 0 \\
\hline $\mathrm{Fe}$ & 0.029 & 0.022 & 0.023 & 0.023 & 0.022 & 0.053 & 0.029 & 0.029 & 0.019 & 0.026 \\
\hline $\mathrm{Mn}$ & 0 & 0.002 & 0.003 & 0.002 & 0.001 & 0.005 & 0.001 & 0 & 0 & 0 \\
\hline $\mathrm{Ca}$ & 0.002 & 0.001 & 0.001 & 0.001 & 0.015 & 0.011 & 0.002 & 0.002 & 0.010 & 0.001 \\
\hline $\mathrm{Ba}$ & 0.002 & 0.002 & 0 & 0 & 0 & 0 & 0 & 0.002 & 0 & 0 \\
\hline Suma $A$ & 1.012 & 1.018 & 1.008 & 1.018 & 0.997 & 1.015 & 1.014 & 1.017 & 1.019 & 1.034 \\
\hline Suma $A+B$ & 2.018 & 2.014 & 2.014 & 2.014 & 2.026 & 2.046 & 2.020 & 2.019 & 2.017 & 2.019 \\
\hline Y+REE & 0.004 & 0.004 & 0.002 & 0.005 & 0.003 & 0.016 & 0.013 & 0.005 & 0.005 & 0.015 \\
\hline
\end{tabular}


s M-/l-typovými magmami. Nízky obsah $\mathrm{CaO}$ (do $4 \mathrm{hm}$. $\%)$ a variabilnejší obsah $\mathrm{MnO}$ indikuje obohatenie protolitu o komponenty vzniknuté metamorfným procesom. Vplyvom zvýšenej prítomnosti vody sa teplota potrebná na kryštalizáciu granátov znižuje (Green 1977, 1992; Harangi et al. 2001; Bach et al. 2012).

Z údajov vyplýva, že vynesením nameraných hodnôt $\mathrm{CaO}$ verzus $\mathrm{MnO}$ získaných z mikrosondových analýz granátov do štandardizovaných diskriminačných polí diagramu (obr. 10) môžeme predpokladat', že skúmané almandínové granáty z lokalít Lesné - Potičky a Beňatinská voda majú vysokotlakový pôvod (nad $7 \mathrm{kbar}$ ) a sú asociované s I-typovými magmami. Charakter chemického zloženia magmatických tavenín zachovaných v podobe inklúzií skla $v$ apatite a ilmenite, ktoré sme identifikovali v granátoch z lokality Lesné - Potičky, spadá do pol'a dacitu a na rozhranie ryolitu a dacitu (obr. 11).

\section{Diskusia}

Z dostupných publikácií dominujú štúdie zamerané na 3D vizualizáciu inklúzií v granátových porfyroblastoch (napr. Huddlestone-Holmes, Ketcham 2005). Na Slovensku prvé 3D vizualizácie priestorovej distribúcie titanitových inklúzií v granáte publikovali Ružička et al. (2013) a Dyda et al. (2017). Parisatto et al. (2018) publikovali štúdiu 3D distribúcie inklúzií tavenín v granátoch. Sieck et al. (2019) publikovali almandínom-obohatené ryolity z Mexika, ktoré obsahovali inklúzie zirkónu, monazitu, apatitu a ilmenitu.

Na základe výsledkov z chemických analýz sa väčšina autorov zhodla, že na obidvoch lokalitách prevláda almandínová zložka v granátoch (Zorkovský 1953; Čech, Matherny 1958; Brousse et al. 1972; Jakabská et al. 1973; Fediuková 1975; Šalát et al. 1979), čo potvrdili aj

Tabul'ka 3 Reprezentatívne elektrónové mikroanalýzy fluórapatitu ( $\mathrm{hm}$. \%) prepočítané na 8 katiónov (apfu). Symbol ${ }^{*}$ vyjadruje dopočítanie $\mathrm{H}_{2} \mathrm{O}$.

\begin{tabular}{|c|c|c|c|c|c|c|c|c|c|c|}
\hline \multirow{2}{*}{$\begin{array}{l}\text { Lokalita } \\
\text { Analýza }\end{array}$} & \multicolumn{5}{|c|}{ Beňatinská voda } & \multicolumn{5}{|c|}{ Lesné - Potičky } \\
\hline & 1 & 2 & 3 & 4 & 5 & 1 & 2 & 3 & 4 & 5 \\
\hline $\mathrm{P}_{2} \mathrm{O}_{5}$ & 41.74 & 41.93 & 41.65 & 41.79 & 41.39 & 42.14 & 42.09 & 42.37 & 42.28 & 42.18 \\
\hline $\mathrm{CaO}^{2}$ & 54.01 & 54.07 & 53.99 & 53.97 & 53.82 & 54.22 & 54.18 & 54.24 & 54.05 & 54.09 \\
\hline $\mathrm{SiO}_{2}$ & 0.13 & 0.23 & 0.08 & 0.18 & 0.37 & 0.11 & 0.16 & 0.19 & 0.14 & 0.16 \\
\hline $\mathrm{TiO}_{2}$ & 0 & 0.05 & 0.07 & 0.08 & 0.01 & 0.11 & 0 & 0 & 0 & 0.08 \\
\hline $\mathrm{FeO}^{2}$ & 0.71 & 0.91 & 0.89 & 0.87 & 0.82 & 0.73 & 0.85 & 0.93 & 0.72 & 0.90 \\
\hline $\mathrm{MnO}$ & 0.07 & 0.03 & 0.03 & 0 & 0.08 & 0.09 & 0.04 & 0.11 & 0.04 & 0.09 \\
\hline $\mathrm{SrO}$ & 0 & 0.08 & 0.03 & 0.05 & 0.03 & 0.02 & 0.03 & 0.01 & 0.04 & 0.01 \\
\hline $\mathrm{Al}_{2} \mathrm{O}_{3}$ & 0.08 & 0.05 & 0.03 & 0.03 & 0.03 & 0.03 & 0.06 & 0.02 & 0.04 & 0.04 \\
\hline $\mathrm{Y}_{2} \mathrm{O}_{3}$ & 0.07 & 0.01 & 0.01 & 0.02 & 0.02 & 0.02 & 0.02 & 0.12 & 0.01 & 0.10 \\
\hline $\mathrm{Ce}_{2} \mathrm{O}_{3}$ & 0.11 & 0.22 & 0.15 & 0.18 & 0.16 & 0.18 & 0.17 & 0.15 & 0.22 & 0.17 \\
\hline $\mathrm{La}_{2} \mathrm{O}_{3}$ & 0.07 & 0.10 & 0.02 & 0.03 & 0.02 & 0.02 & 0.06 & 0.03 & 0.02 & 0.06 \\
\hline $\mathrm{Nd}_{2} \mathrm{O}_{3}$ & 0.10 & 0.08 & 0.09 & 0.09 & 0.08 & 0.11 & 0.05 & 0.16 & 0.12 & 0.18 \\
\hline $\mathrm{Sm}_{2} \mathrm{O}_{3}$ & 0 & 0.03 & 0.01 & 0.04 & 0.09 & 0.05 & 0.02 & 0 & 0.02 & 0.04 \\
\hline $\mathrm{Pr}_{2} \mathrm{O}_{3}$ & 0 & 0 & 0 & 0 & 0.04 & 0.01 & 0.02 & 0 & 0.06 & 0.14 \\
\hline $\mathrm{F}$ & 2.24 & 2.41 & 2.33 & 2.17 & 2.27 & 2.72 & 2.35 & 2.42 & 2.52 & 2.29 \\
\hline $\mathrm{Cl}$ & 0.26 & 0.24 & 0.24 & 0.28 & 0.25 & 0.27 & 0.29 & 0.28 & 0.26 & 0.26 \\
\hline $\mathrm{H}_{2} \mathrm{O}^{*}$ & 0.64 & 0.57 & 0.60 & 0.67 & 0.63 & 0.42 & 0.59 & 0.57 & 0.51 & 0.63 \\
\hline$-\mathrm{O}=\mathrm{F}$ & -0.94 & -1.01 & -0.98 & -0.91 & -0.95 & -1.15 & -0.99 & -1.02 & -1.06 & -0.97 \\
\hline$-\mathrm{O}=\mathrm{Cl}$ & -0.06 & -0.05 & -0.05 & -0.06 & -0.06 & -0.06 & -0.07 & -0.06 & -0.06 & -0.06 \\
\hline Suma & 99.21 & 99.93 & 99.17 & 99.48 & 99.07 & 100.02 & 99.93 & 100.50 & 99.94 & 100.40 \\
\hline$P$ & 3.000 & 2.997 & 2.996 & 2.999 & 2.981 & 3.010 & 3.007 & 3.013 & 3.023 & 3.006 \\
\hline $\mathrm{Si}$ & 0.011 & 0.020 & 0.007 & 0.015 & 0.031 & 0.010 & 0.014 & 0.016 & 0.012 & 0.014 \\
\hline $\mathrm{Ti}$ & 0 & 0.003 & 0.005 & 0.005 & 0.001 & 0.007 & 0 & 0 & 0 & 0.005 \\
\hline Suma $T$ & 3.000 & 2.997 & 2.996 & 2.999 & 2.981 & 3.010 & 3.007 & 3.013 & 3.023 & 3.006 \\
\hline $\mathrm{Ca}$ & 4.914 & 4.892 & 4.915 & 4.902 & 4.906 & 4.901 & 4.898 & 4.881 & 4.892 & 4.879 \\
\hline $\mathrm{Fe}$ & 0.051 & 0.065 & 0.063 & 0.062 & 0.058 & 0.051 & 0.060 & 0.065 & 0.051 & 0.063 \\
\hline $\mathrm{Mn}$ & 0.005 & 0.002 & 0.002 & 0 & 0.005 & 0.006 & 0.003 & 0.008 & 0.003 & 0.007 \\
\hline $\mathrm{Sr}$ & 0 & 0.004 & 0.002 & 0.003 & 0.002 & 0.001 & 0.001 & 0.001 & 0.002 & 0.001 \\
\hline $\mathrm{Al}$ & 0.008 & 0.005 & 0.003 & 0.003 & 0.003 & 0.003 & 0.006 & 0.002 & 0.004 & 0.004 \\
\hline$Y$ & 0.003 & 0 & 0.001 & 0.001 & 0.001 & 0.001 & 0.001 & 0.005 & 0 & 0.005 \\
\hline $\mathrm{Ce}$ & 0.003 & 0.007 & 0.005 & 0.006 & 0.005 & 0.006 & 0.005 & 0.005 & 0.007 & 0.005 \\
\hline $\mathrm{La}$ & 0.002 & 0.003 & 0.001 & 0.001 & 0.001 & 0.001 & 0.002 & 0.001 & 0.001 & 0.002 \\
\hline $\mathrm{Nd}$ & 0.003 & 0.002 & 0.003 & 0.002 & 0.002 & 0.003 & 0.001 & 0.004 & 0.003 & 0.005 \\
\hline $\mathrm{Sm}$ & 0 & 0.001 & 0 & 0.001 & 0.003 & 0.001 & 0.001 & 0 & 0.001 & 0.001 \\
\hline $\mathrm{Pr}$ & 0 & 0 & 0 & 0 & 0.001 & 0 & 0.001 & 0 & 0.002 & 0.004 \\
\hline Suma $M$ & 4.989 & 4.980 & 4.992 & 4.981 & 4.987 & 4.974 & 4.980 & 4.972 & 4.965 & 4.975 \\
\hline $\mathrm{F}^{-}$ & 0.600 & 0.643 & 0.626 & 0.582 & 0.609 & 0.726 & 0.628 & 0.642 & 0.674 & 0.611 \\
\hline $\mathrm{Cl}^{-}$ & 0.037 & 0.035 & 0.034 & 0.040 & 0.036 & 0.038 & 0.042 & 0.040 & 0.038 & 0.037 \\
\hline $\mathrm{OH}^{-}$ & 0.362 & 0.323 & 0.340 & 0.378 & 0.355 & 0.236 & 0.330 & 0.318 & 0.288 & 0.352 \\
\hline Suma $X$ & 1.000 & 1.000 & 1.000 & 1.000 & 1.000 & 1.000 & 1.000 & 1.000 & 1.000 & 1.000 \\
\hline
\end{tabular}


Tabul'ka 4 Reprezentatívne elektrónové mikroanalýzy ilmenitu ( $\mathrm{hm}$. \%) prepočítané na 2 katióny (apfu).

\begin{tabular}{lrrrrr}
\hline Lokalita & \multicolumn{5}{c}{ Lesné - Potičky } \\
\hline Analýza & 1 & 2 & 3 & 4 & 5 \\
\hline $\mathrm{SiO}_{2}$ & 0.02 & 0.04 & 0.02 & 0.02 & 0.02 \\
$\mathrm{TiO}_{2}$ & 50.73 & 49.10 & 49.53 & 48.71 & 50.35 \\
$\mathrm{Al}_{2} \mathrm{O}_{3}$ & 0.09 & 0.08 & 0.10 & 0.09 & 0.08 \\
$\mathrm{FeO}_{\mathrm{t}}$ & 46.31 & 46.56 & 45.94 & 46.49 & 45.76 \\
$\mathrm{MnO}_{\mathrm{MgO}}$ & 0.55 & 0.57 & 0.60 & 0.53 & 0.57 \\
$\mathrm{ZnO}$ & 0.61 & 0.58 & 0.57 & 0.54 & 0.55 \\
$\mathrm{Suma}$ & 0.03 & 0 & 0.07 & 0.03 & 0.04 \\
\hline $\mathrm{Si}$ & 98.33 & 96.93 & 96.83 & 96.39 & 97.37 \\
$\mathrm{Ti}$ & 0.001 & 0.001 & 0.001 & 0 & 0.001 \\
$\mathrm{Al}$ & 0.973 & 0.955 & 0.965 & 0.953 & 0.976 \\
$\mathrm{Fe}$ & 0.003 & 0.003 & 0.003 & 0.003 & 0.002 \\
$\mathrm{Mn}$ & 0.988 & 1.007 & 0.995 & 1.011 & 0.986 \\
$\mathrm{Mg}$ & 0.012 & 0.012 & 0.013 & 0.012 & 0.013 \\
$\mathrm{Zn}$ & 0.023 & 0.022 & 0.022 & 0.021 & 0.021 \\
$\mathrm{Suma}$ & 0 & 0 & 0.001 & 0.001 & 0.001 \\
\hline
\end{tabular}

naše analýzy. $V$ ryodacitoch z Beňatinskej vody granáty tvoria $0.12-3.70$ obj. \% horniny, kým v Lesnianskych ryolitoch bolo stanovené zastúpenie granátov $v$ rozsahu 0.08 - 1.5 obj. \% (Jakabská, Timčák 1978; Šalát et al. 1979). Čech a Matherny (1958) skúmali morfológiu granátov z ryolitov južne od Lesného a podla ich vyjadrenia prestavujú spojky tetragón-tri-oktaédra, ktorý prevláda nad rombododekaédrom. Slávik (1970) považuje almandínové granáty za typomorfné minerály potvrdzujúce prítomnost' ryodacitových extrúzií v neovulkanitoch Vihorlatu.
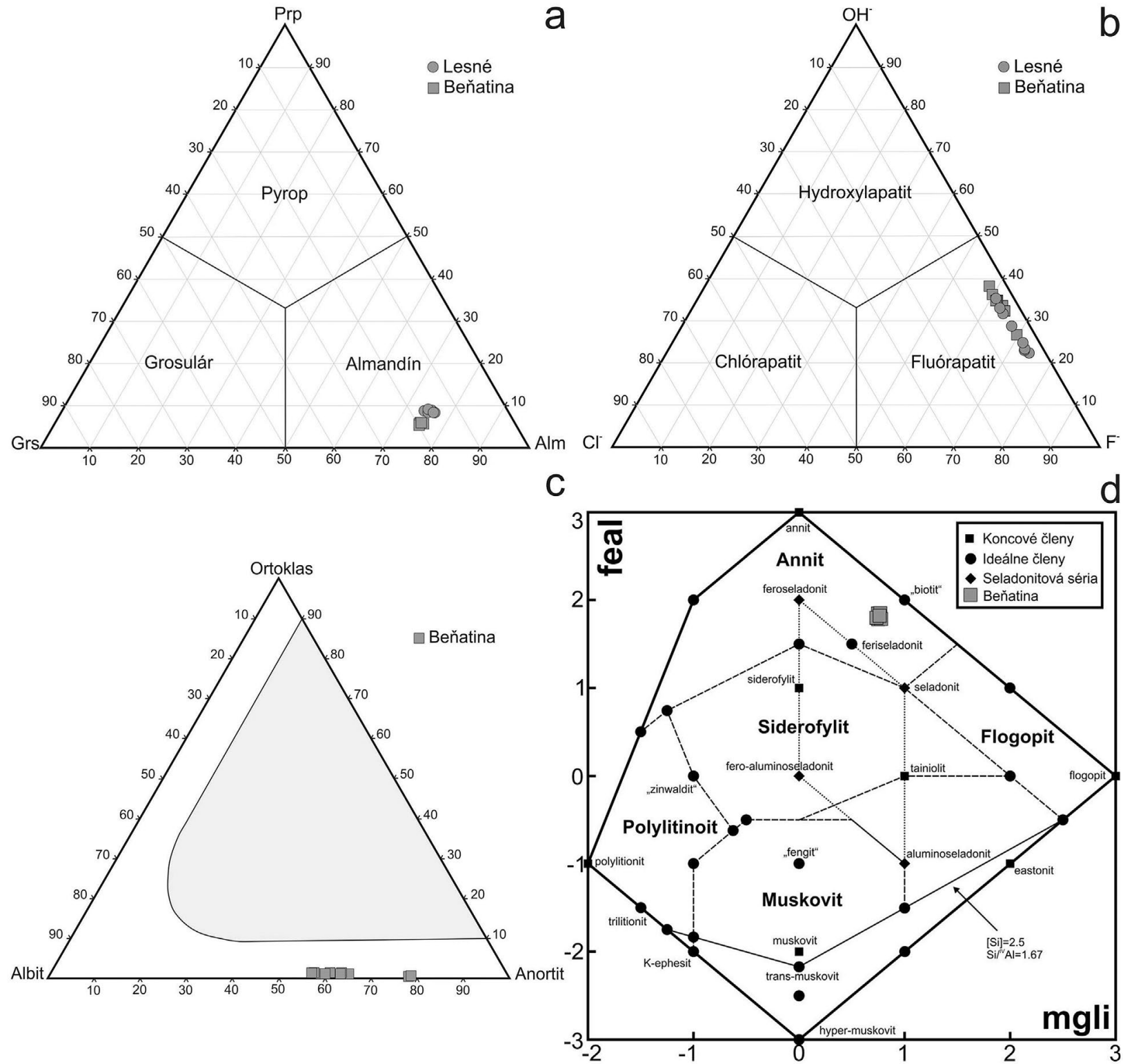

Obr. 9 Analyzované fázy vynesené do klasifikačných diagramov: a) granátová superskupina (Grew et al. 2013); b) apatitová superskupina (Pasero et al. 2010); c) živce; d) sl'udy (Tischendorf et al. 2007). 
Podla Konečného et al. (2010) majú almandínové granáty $v$ ryolitových až ryodacitových extrúziách Lesné a Beňatina, ktoré vznikli počas sarmatského vulkanizmu, pomerne homogénne zloženie a obsahujú inklúzie zirkónu a apatitu magmatického pôvodu. Fenokrysty granátov s rozmermi od 0.2 do $3 \mathrm{~mm}$ pravdepodobne vznikli pri kryštalizácii magmy $v$ magmatickom rezervoári v híbke cca 50 až $70 \mathrm{~km}$ za vysokých tlakov (Zorkovský 1953; Šalát et al. 1979). Magmatické granáty s dominantným almandínovým zložením môžu kryštalizovat' $v$ híbke nad $25 \mathrm{~km}$ priamo $v$ magmatickom rezervoári s M-/l-typovými magmatickými taveninami pri tlakoch nad 7 kbar a teplote $\sim 1000{ }^{\circ} \mathrm{C}$, pričom dosahujú hodnoty $\mathrm{MnO}$ do $2 \mathrm{hm}$. \% a obsah $\mathrm{CaO}$ nad $5 \mathrm{hm}$. \% (Green 1977, 1992; Harangi et al. 2001; Bach et al. 2012). Granáty analyzované $v$ tejto práci z lokalít Lesné a Beňatina dosahujú hodnoty $\mathrm{CaO}$ v intervale $5.24-6.90 \mathrm{hm}$. \% a $\mathrm{MnO} 0.84-1.71 \mathrm{hm} . \%$, čo potvrdzuje ich predpokladaný genetický pôvod zhodujúci sa s prácami predchádzajúcich autorov.

\section{Záver}

Priestorové zobrazenie reálnej objemovej distribúcie a vel'kostí zosnímaných minerálnych inklúzií v granátoch umožňuje nedeštruktívnym spôsobom získat' doplňujúce informácie priebehu genetických procesov, ktoré sa odohrali počas geodynamického vývoja skúmanej oblasti. Pomocou rtg. mikrotomografie bolo priestorovo zobrazených 126 minerálnych inklúzií v granáte z Beňatinskej vody a 21 inklúzií v granáte z lokality Lesné - Potičky, pričom každá inklúzia má stanovený objem a vizualizovanú priestorovú pozíciu. Podl'a 3D zobrazenia minerálnych inklúzií a na základe ich mikrosondových analýz predpokladáme, že zobrazené tvary zodpovedajú inklúziám zirkónov, fluórapatitom, ilmenitom a pyritom, ktoré obsahujú rtg. kontrastnejšie prvky, umožňujúce ich výraznejšie obrysové vyobrazenie tvarov.

Zastúpenie troch dominantných koncových členov v rámci zloženia granátov z lokality Lesné - Potičky je nasledovné $\operatorname{Alm}_{71.0-73.7} \operatorname{Prp}_{8.3-9.0} \mathrm{Grs}_{14.7-16.6}$ na rozdiel od zloženia granátov $z$ Beňatinskej vody $\mathrm{Alm}_{72.1-73.2} \operatorname{Prp}_{5.55-5.9}$ $\mathrm{Grs}_{183-194 .}$. Na základe chemického zloženia sa potvrdil vysokotlakový pôvod granátov asociovaných s I-typovými magmami.

Zloženie inklúzií zirkónov a fluórapatitov v granátoch $z$ obidvoch skúmaných lokalít je vel'mi podobné. Rozdiely sú hlavne v zastúpení ostatných inklúzií, pričom v granátoch z lokality Lesné - Potičky bol identifikovaný ilmenit, annit a tavenina uzavretá v inklúziách apatitu, kým v granátoch z Beňatinskej vody bol prítomný bázický plagioklas dominantnejšie zastúpený anortitovým komponentom.

\section{Pod'akovanie}

Táto práca bola podporovaná Agentúrou na podporu výskumu a vývoja na základe zmluvy č. APVV-15-0050 a grantom VEGA 1/0151/19. Vyslovujeme pod'akovanie recenzentom článku za podnetné pripomienky, ktoré prispeli k skvalitneniu rukopisu.

Tabul'ka 5 Reprezentatívne elektrónové mikroanalýzy plagioklasov (hm. \%) prepočítané na 5 katiónov (apfu). Obsahy $\mathrm{FeO}$ a $\mathrm{Fe}_{2} \mathrm{O}_{3}$ boli prepočítané na základe nábojovej bilancie molekuly.

\begin{tabular}{|c|c|c|c|c|c|c|c|c|}
\hline Lokalita & & & & eňatins & & & & \\
\hline Analýza & 1 & 2 & 3 & 4 & 5 & 6 & 7 & 8 \\
\hline $\mathrm{SiO}_{2}$ & 53.67 & 52.23 & 48.53 & 53.59 & 52.88 & 53.09 & 48.30 & 52.03 \\
\hline $\mathrm{Al}_{2} \mathrm{O}_{3}$ & 28.95 & 29.48 & 32.09 & 28.91 & 29.26 & 29.18 & 32.40 & 30.04 \\
\hline $\mathrm{Fe}_{2} \mathrm{O}_{3}$ & 0 & 0 & 0 & 0 & 0 & 0 & 0 & 0 \\
\hline $\mathrm{FeO}$ & 0.70 & 0.79 & 0.60 & 0.75 & 0.64 & 0.57 & 0.69 & 0.66 \\
\hline $\mathrm{MnO}$ & 0.03 & 0.04 & 0.07 & 0.07 & 0.06 & 0.04 & 0.06 & 0.07 \\
\hline $\mathrm{SrO}$ & 0.09 & 0.05 & 0.05 & 0.09 & 0.03 & 0.04 & 0.05 & 0.07 \\
\hline $\mathrm{CaO}$ & 11.68 & 12.53 & 15.48 & 11.40 & 12.14 & 11.99 & 15.59 & 12.76 \\
\hline $\mathrm{Na}_{2} \mathrm{O}$ & 4.40 & 3.91 & 2.36 & 4.59 & 4.21 & 4.38 & 2.30 & 3.73 \\
\hline $\mathrm{K}_{2} \mathrm{O}$ & 0.18 & 0.19 & 0.06 & 0.21 & 0.20 & 0.19 & 0.09 & 0.18 \\
\hline Suma & 99.69 & 99.21 & 99.24 & 99.61 & 99.42 & 99.46 & 99.47 & 99.54 \\
\hline $\mathrm{Si}^{4+}$ & 2.438 & 2.393 & 2.240 & 2.438 & 2.413 & 2.420 & 2.227 & 2.376 \\
\hline${ }^{\mathrm{IV}} \mathrm{Al}^{3+}$ & 0.562 & 0.607 & 0.760 & 0.562 & 0.587 & 0.580 & 0.773 & 0.624 \\
\hline${ }_{\mathrm{V}}^{\mathrm{I}} \mathrm{Al}^{3+}$ & 0.989 & 0.984 & 0.986 & 0.989 & 0.987 & 0.988 & 0.987 & 0.992 \\
\hline Suma $T$ & 3.989 & 3.984 & 3.986 & 3.989 & 3.987 & 3.988 & 3.987 & 3.992 \\
\hline $\mathrm{Fe}^{2+}$ & 0.027 & 0.030 & 0.023 & 0.029 & 0.024 & 0.022 & 0.026 & 0.025 \\
\hline $\mathrm{Mn}^{2+}$ & 0.001 & 0.001 & 0.003 & 0.003 & 0.002 & 0.002 & 0.002 & 0.003 \\
\hline $\mathrm{Sr}^{2+}$ & 0.002 & 0.001 & 0.001 & 0.002 & 0.001 & 0.001 & 0.001 & 0.002 \\
\hline $\mathrm{Ca}^{2+}$ & 0.569 & 0.615 & 0.766 & 0.556 & 0.594 & 0.585 & 0.770 & 0.624 \\
\hline $\mathrm{Na}^{+}$ & 0.388 & 0.347 & 0.211 & 0.405 & 0.372 & 0.387 & 0.206 & 0.331 \\
\hline $\mathrm{K}^{+}$ & 0.010 & 0.011 & 0.003 & 0.012 & 0.012 & 0.011 & 0.005 & 0.010 \\
\hline Suma $M$ & 0.997 & 1.006 & 1.008 & 1.007 & 1.005 & 1.007 & 1.011 & 0.995 \\
\hline Albit & 40.13 & 35.66 & 21.55 & 41.60 & 38.08 & 39.35 & 20.95 & 34.24 \\
\hline Anortit & 58.81 & 63.18 & 78.10 & 57.12 & 60.72 & 59.54 & 78.53 & 64.68 \\
\hline Ortoklas & 1.06 & 1.16 & 0.35 & 1.28 & 1.21 & 1.11 & 0.52 & 1.08 \\
\hline
\end{tabular}


Tabul'ka 6 Reprezentatívne elektrónové mikroanalýzy slúd (hm. \%) prepočítané na 11 kyslíkov (apfu). Symbol *vyjadruje dopočítanie $\mathrm{H}_{2} \mathrm{O}$. Obsahy $\mathrm{FeO}$ a $\mathrm{Fe}_{2} \mathrm{O}_{3}$ boli prepočítané na základe nábojovej bilancie molekuly.

\begin{tabular}{|c|c|c|c|c|c|c|}
\hline Lokalita & & & Lesné & & & \\
\hline Analýza & 1 & 2 & 3 & 4 & 5 & 6 \\
\hline $\mathrm{SiO}_{2}$ & 35.68 & 35.62 & 36.11 & 36.24 & 35.88 & 35.97 \\
\hline $\mathrm{TiO}_{2}$ & 4.24 & 4.17 & 4.63 & 4.64 & 4.20 & 4.19 \\
\hline $\mathrm{Al}_{2} \mathrm{O}_{3}$ & 15.30 & 15.26 & 15.28 & 15.39 & 15.32 & 15.51 \\
\hline $\mathrm{Fe}_{2} \mathrm{O}_{3}$ & 0 & 0 & 0 & 0 & 0 & 0 \\
\hline $\mathrm{FeO}$ & 26.89 & 26.09 & 26.25 & 25.79 & 26.46 & 26.03 \\
\hline $\mathrm{MnO}$ & 0.07 & 0.08 & 0.13 & 0.13 & 0.20 & 0.08 \\
\hline $\mathrm{MgO}$ & 6.37 & 6.44 & 6.59 & 6.41 & 6.92 & 6.99 \\
\hline $\mathrm{Na}_{2} \mathrm{O}$ & 0.19 & 0.21 & 0.18 & 0.29 & 0.24 & 0.18 \\
\hline $\mathrm{K}_{2} \mathrm{O}$ & 9.08 & 9.08 & 9.12 & 8.76 & 9.03 & 9.09 \\
\hline $\mathrm{BaO}$ & 0.45 & 0.50 & 0.46 & 0.46 & 0.48 & 0.56 \\
\hline $\mathrm{F}$ & 0 & 0 & 0 & 0.05 & 0.49 & 0.09 \\
\hline $\mathrm{Cl}$ & 0.13 & 0.14 & 0.14 & 0.13 & 0.15 & 0.14 \\
\hline $\mathrm{H}_{2} \mathrm{O}^{*}$ & 3.87 & 3.85 & 3.90 & 3.88 & 3.70 & 3.87 \\
\hline$-\mathrm{O}=\mathrm{F}$ & 0 & 0 & 0 & -0.02 & -0.21 & -0.04 \\
\hline$-\mathrm{O}=\mathrm{Cl}$ & -0.03 & -0.03 & -0.03 & -0.03 & -0.03 & -0.03 \\
\hline Suma & 102.25 & 101.40 & 102.76 & 102.11 & 102.82 & 102.60 \\
\hline $\mathrm{Si}^{4+}$ & 2.741 & 2.751 & 2.749 & 2.762 & 2.708 & 2.736 \\
\hline${ }^{\mathrm{IV}} \mathrm{Al}^{3+}$ & 1.259 & 1.249 & 1.251 & 1.238 & 1.292 & 1.264 \\
\hline Suma $T$ & 4.000 & 4.000 & 4.000 & 4.000 & 4.000 & 4.000 \\
\hline $\mathrm{Ti}^{4+}$ & 0.245 & 0.242 & 0.265 & 0.266 & 0.238 & 0.240 \\
\hline${ }^{\mathrm{V}} \mathrm{Al}^{3+}$ & 0.126 & 0.141 & 0.120 & 0.144 & 0.070 & 0.127 \\
\hline $\mathrm{Fe}^{2+}$ & 1.727 & 1.685 & 1.671 & 1.644 & 1.670 & 1.656 \\
\hline $\mathrm{Mn}^{2+}$ & 0.004 & 0.005 & 0.008 & 0.008 & 0.013 & 0.005 \\
\hline $\mathrm{Mg}^{2+}$ & 0.729 & 0.741 & 0.748 & 0.729 & 0.779 & 0.793 \\
\hline$\square$ & 0.168 & 0.185 & 0.188 & 0.209 & 0.230 & 0.180 \\
\hline Suma $M$ & 3.000 & 3.000 & 3.000 & 3.000 & 3.000 & 3.000 \\
\hline $\mathrm{Ba}^{2+}$ & 0.013 & 0.015 & 0.014 & 0.014 & 0.014 & 0.017 \\
\hline $\mathrm{Na}^{+}$ & 0.028 & 0.031 & 0.027 & 0.043 & 0.035 & 0.026 \\
\hline $\mathrm{K}^{+}$ & 0.889 & 0.895 & 0.886 & 0.852 & 0.870 & 0.882 \\
\hline$\square$ & 0.069 & 0.059 & 0.073 & 0.091 & 0.081 & 0.076 \\
\hline Suma I & 1.000 & 1.000 & 1.000 & 1.000 & 1.000 & 1.000 \\
\hline $\mathrm{F}^{-}$ & 0 & 0 & 0 & 0.013 & 0.117 & 0.021 \\
\hline $\mathrm{Cl}^{-}$ & 0.017 & 0.018 & 0.018 & 0.016 & 0.019 & 0.018 \\
\hline $\mathrm{OH}^{-}$ & 1.983 & 1.982 & 1.982 & 1.971 & 1.864 & 1.962 \\
\hline Suma $A$ & 2.000 & 2.000 & 2.000 & 2.000 & 2.000 & 2.000 \\
\hline
\end{tabular}

Tabul'ka 7 Reprezentatívne elektrónové mikroanalýzy magmatických tavenín (hm. \%).

\begin{tabular}{lrrrrr}
\hline Lokalita & \multicolumn{5}{c}{ Lesné - Potičky } \\
\hline Analýza & 1 & 2 & 3 & 4 & 5 \\
\hline $\mathrm{P}_{2} \mathrm{O}_{5}$ & 0.34 & 0.09 & 4.64 & 3.70 & 3.31 \\
$\mathrm{SiO}_{2}$ & 74.42 & 71.70 & 73.01 & 71.40 & 72.09 \\
$\mathrm{TiO}_{2}$ & 0.11 & 0.09 & 0.06 & 0.06 & 0 \\
$\mathrm{Al}_{2} \mathrm{O}_{3}$ & 12.73 & 12.65 & 12.4 & 12.52 & 12.43 \\
$\mathrm{FeO}_{\text {Total }}$ & 0.49 & 1.21 & 0.27 & 0.39 & 0.45 \\
$\mathrm{MnO}$ & 0.09 & 0.05 & 0.08 & 0.08 & 0.01 \\
$\mathrm{MgO}$ & 0 & 0.09 & 0.02 & 0.01 & 0.01 \\
$\mathrm{SrO}$ & 0.04 & 0.01 & 0.06 & 0.04 & 0.04 \\
$\mathrm{BaO}$ & 0.04 & 0.16 & 0.08 & 0.03 & 0.05 \\
$\mathrm{CaO}$ & 2.40 & 2.46 & 3.14 & 4.20 & 4.20 \\
$\mathrm{Na}$ & 0.71 & 0.95 & 0.47 & 0.36 & 0.49 \\
$\mathrm{~K}_{2} \mathrm{O}$ & 1.69 & 4.14 & 1.21 & 1.25 & 1.08 \\
\hline $\mathrm{Suma}$ & 93.05 & 93.61 & 95.06 & 94.02 & 94.16 \\
\hline
\end{tabular}


Obr. 10 Zobrazenie analyzovaných granátov $v \mathrm{CaO}$ vs. MnO diagrame podla Harangi et al. (2001).

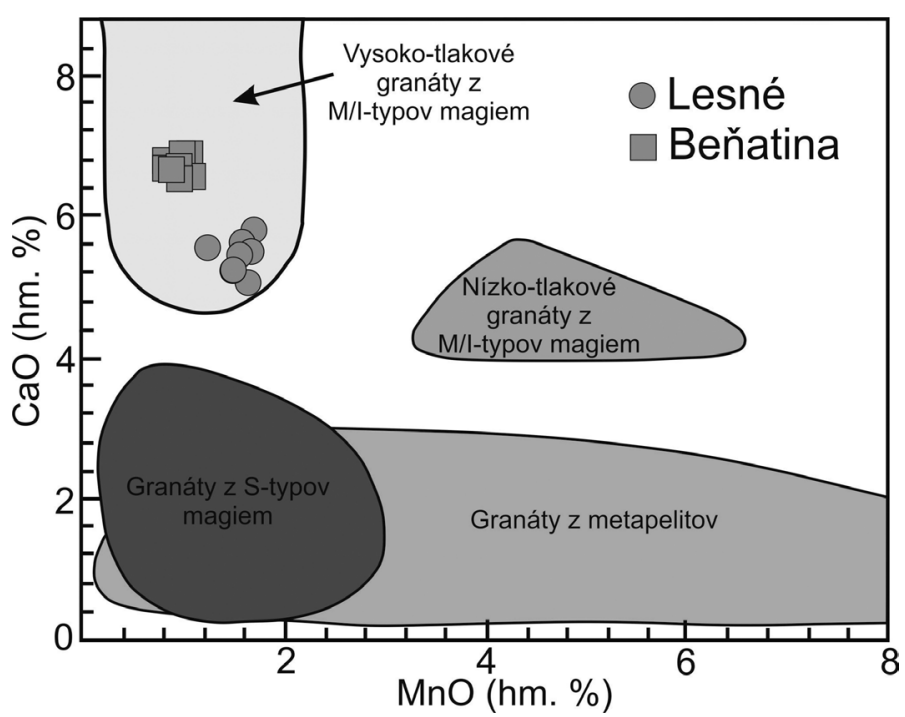

Obr. 11 Analyzované taveniny $v$ granátoch z lokality Lesné - Potičky zobrazené v TAS (Total Alkali vs. Silica) diagrame (Le Bas et al. 1986).

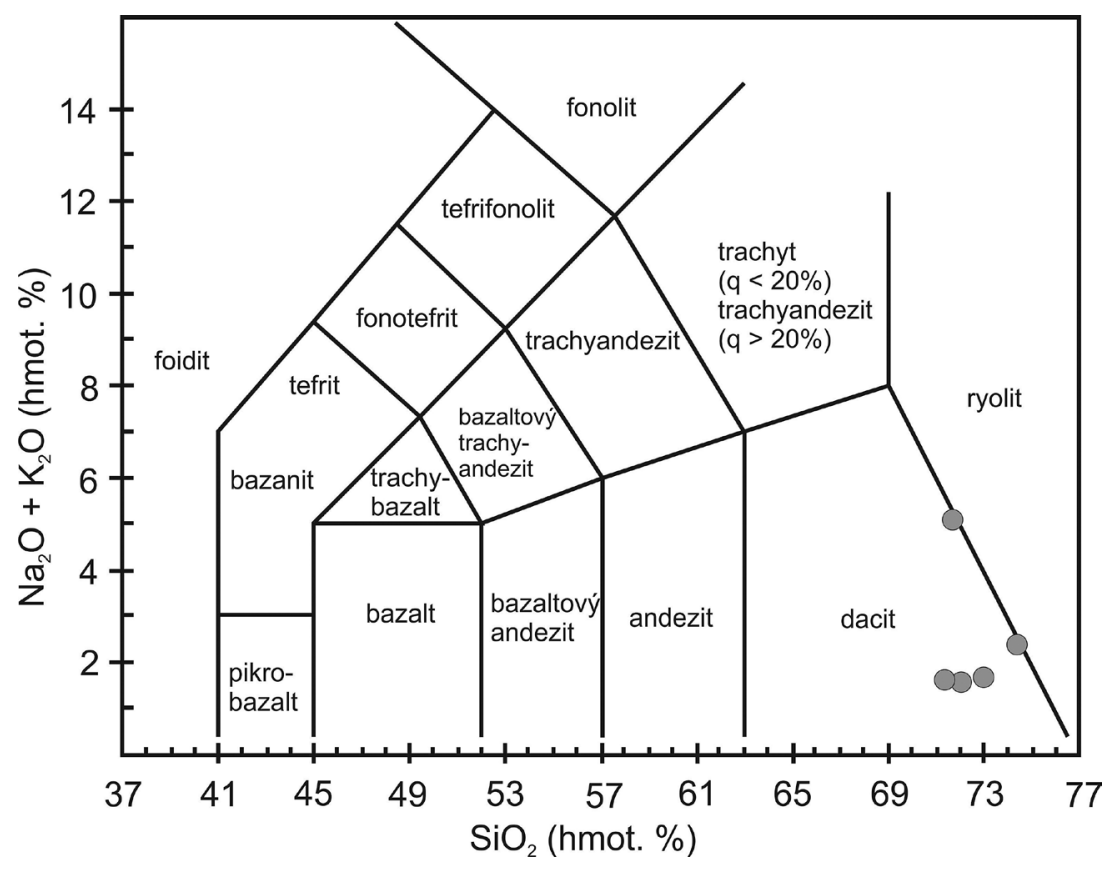

\section{Literatúra}

BACH P, SMith I E M, MaLPAS J G (2012) The origin of garnets in andesitic rocks from the Northland Arc, New Zealand, and their implication for sub-arc processes. J Petrol 53(6): 1169-1195

BAŇACKÝ V (1988) Geologická mapa severnej časti Východoslovenskej nížiny 1: 50 000. ŠGÚDŠ, Bratislava

BAŇACKÝ V, VASS D, KaličIAK M, Remšík A, Pospišıl L' (1987) Vysvetlivky ku geologickej mape severnej časti Východoslovenskej nížiny 1: 50 000. ŠGúDŠ, Bratislava, 7-117

Brousse R, Bizouard H, Šalát J (1972) Grenats des andésites et des rhyoilites de Slovaquie, origine des grenats dans les séries andésitiques. Contr Miner Petrol 35: 201-213

ČeCh F, MAtherny M (1958) Granáty z ryolitov (lok. Lesné) a tufitov podvihorlatskej uhol'nej panvy (lok. Hnojné). Geol Zbor Geol Carpath 9, 2: 241-252

DYDA M, RužıČKA P, HAIN M (2017) Crystal size distribution (CSD) of titanite inclusions in grossular from a calcsilicate rock in the Malé Karpaty Mts., Slovakia. Miner Slov 49, 2: 113-123
Fediuková E (1975) Garnets from neovolcanics in Slovakia. Krystalinikum 11: 53-62

GREEN T H (1992) Experimental phase equilibrium studies of garnet-bearing l-type volcanics and high-level intrusives from Northland, New Zealand. Trans Royal Soc Edinburgh, Earth Sci 83: 429-438

GrEEN T H (1977) Garnet in silicic liquids and its possible use as a P-T indicator. Contr Miner Petrol 65(1): 59-67

Grew E S, Locock A J, Mills S J, Galuskina I O, Galuskine $\checkmark$, HÁlenius U (2013) Nomenclature of the garnet supergroup. Am Miner 98: 785-811

Harangi S, Downes H, Kósa L, Szabó C, Thirlwall M F, MASON P R D, MATTEY D (2001) Almandine garnet in calc-alkaline volcanic rocks of the Northern Pannonian Basin (Eastern-Central Europe): Geochemistry, petrogenesis and geodynamic implications. J Petrol 42(10): 1813-1843

Huddlestone-Holmes C R, Ketcham R A (2005) Getting the inside story: using computed $\mathrm{X}$-ray tomography to study inclusion trails in garnet porphyroblasts. Am Miner 90, 11-12: 1-17 
JAKABSKÁ K, TIMČÁK G (1978) The determination of garnet content of rocks by different methods. Geol Zbor Geol Carpath 29, 1: 161-166

JAKABSKÁ K, TIMČÁK G, FIAČANOVÁ E, ČINČÁROVÁ M (1973) The relation of microhardness to the physical and chemical properties of garnets from volcanic rocks of the West Carpathians. Geol Zbor Geol Carpath 24, 1: 177-190

Kaličiak M, KoneČný V, Lexa J, Konečný P (1995) Geologická stavba Vihorlatských vrchov. Záp Karpaty, sér geol 18: 7-98

KoneČnÝ P, Bačo P, KoneČnÝ V (2010) Acid Miocene volcanism in the Eastern Slovakia, variable sources and magma forming processes: constraints from petrology and geochemistry. XIX Congress of the Carpathian-Balkan Geological Association. In: Geologica Balcanica Abstracts Volume. Chatzipetros A, Melfos V, Marchev P, Lakova I, (Eds). Thessaloniki, Greece, 199-200

Le Bas MJ, Le Maitre RW, Streckeisen A, Zanettin B (1986) A chemical classification of volcanic rocks based on the total alkali-silica diagram. J Petrol 27: 745-750

MAZÚR E, LUKNIŠ M (1980) Geomorfologické jednotky (mapa 1: 500 000). In: Mazúr E, Jakál J (eds.): Atlas SSR. SAV a Slov úrad geod a kart Bratislava, 54-55

Ozdín D, UHeR P (2002) Slovenské názvy minerálov. Minerály schválené Medzinárodnou mineralogickou asociáciou do konca roku 2001. ŠGúDŠ, Bratislava, 1-195

Parisatto M, Turina A, Cruciani G, Mancini L, Peruzzo L, Cesare B (2018) Three-dimensional distribution of primary melt inclusions in garnets by X-ray microtomography. Am Miner 103: 911-926

Pasero M, Kampf AR, Ferraris C, Pekov IV, Rakovan J, WHITE TJ (2010) Nomenclature of the apatite supergroup minerals. Eur J Mineral 22: 163-179

Pécskay Z, Lexa J, Szakács A, Balogh K, Seghedi I, Konečný V, Kovács M, Márton E, Kaličiak M, Széky-Fux V, Póka T, Gyarmatı P, Edelstein O, Rosu E, Žec B (1995) Space and time distribution of Neogene-Quaternary volcanism in the Carpatho-Pannonian region. Acta Vulcanol 7, 2: 15-28

Pécskay Z, Seghedi I, Downes H, Prychodko M, Mackiv B (2000) K/Ar dating of Neogene calc-alkaline volcanic rocks from transcarpathian Ukraine. Geol Carpath 51, 2: $83-89$
Pécskay Z, Kaličiak M, Konečný V, LeXa J, Žec B (2002) Geochronology of the Neogene volcanism in the Vihorlatské vrchy mountain range, Eastern Slovakia. Proceedings of XVII. Congress of Carpathian-Balkan Geological Asssociation. Geol Carpath 53, Spec Issue: 203-205

RuŽıČKa P, HaIN M, BaČík P, MıLovSKÁ S, JuHÁSz P (2013) 3D distribúcia titanitových inklúzií $v$ granáte $z$ lokality Modra-Harmónia (Malé Karpaty, Slovensko). Bull mineral-petrolog Odd Nár Muz (Praha) 21, 2: 131-142

Vass D, Töszér J, Bagdasarjan G P, KaličIak M, Orlický O, DúricA D (1978) Chronológia vulkanických udalostí na východnom Slovensku vo svetle izotopických a paleomagnetických výskumov. Geol Práce Spr 71: 77-88

Sieck P, Lopez-Doncel R, Davila-Harris P, Aguillon-Robles A, WeMmer K, MAURY R C (2019) Almandine garnet-bearing rhyolites associated to bimodal volcanism in the Mesa Central of Mexico: Geochemical, petrological and geochronological evolution. J South Amer Earth Sci 92: 310-328

SLÁVIK J (1970) Minerály rozsypov vulkanitov Vihorlatu, ich geologický a prospekčný význam. Miner Slov 2, 7: $231-248$

Šalát J, RoZložník L, TIMČÁK G, JaKABSKÁ K, ČINČÁROVÁ M (1979) Vlastnosti granátov neovulkanitov Západných Karpát a ich petrologická interpretácia. In: Sympózium o petrogenéze a geochémii geologických procesov. Veda, Bratislava, 231-242

Tischendorf G, Förster H J, Gottesmann B, Rieder M (2007) True and brittle micas: composition and solidsolution series. Mineral Mag 71, 3: 285-320

ZoRKovskÝ B (1953) Granát z granatického ryolitu z lokality „Potičky" južne od obce Lesná na východnom Slovensku. Geol Zbor Geol Carpath 4, 3-4: 823-824

Žec B (ed.), Kaličiak M, Konečný V, LeXa J, Jacko S mL, KaRoli S, Bañacký V, Potfaj M, Rakús M, Petro L', Spišák Z (1997a) Geologická mapa Vihorlatských a Humenských vrchov $1: 50$ 000. ŠGÚDŠ, Bratislava

Žec B (ed.), Kaličiak M, KoneČný V, Lexa J, Jacko $S$ mL, Bañacký V, Karoli $S$, Potfaj $M$, Rakús $M$, Petro l', SPIŠÁk Z, BodnÁr J, Jetel J, Boorová D, ZLinská A (1997b) Vysvetlivky ku geologickej mape Vihorlatských a Humenských vrchov 1 : 50 000. ŠGÚDŠ, Bratislava, 5-254 